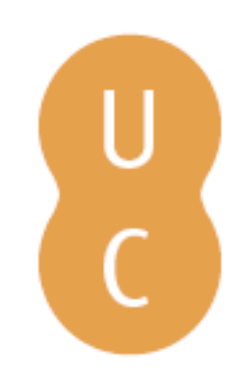

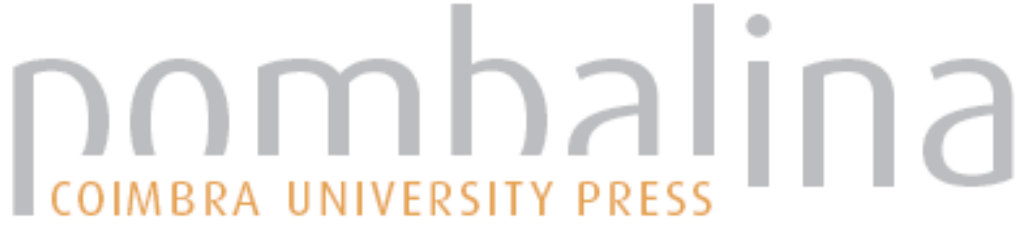

Da pólis à cosmópolis: dos mosteiros cistercienses portugueses ao capítulo geral de Cister
Autor(es):
Marques, Maria Alegria
Publicado por: Imprensa da Universidade de Coimbra; Annablume
URL
persistente:
URI:http://hdl.handle.net/10316.2/40822
DOI:
DOI:https://doi.org/10.14195/978-989-26-1280-5_9
Accessed : $\quad$ 26-Apr-2023 12:34:25

A navegação consulta e descarregamento dos títulos inseridos nas Bibliotecas Digitais UC Digitalis, UC Pombalina e UC Impactum, pressupõem a aceitação plena e sem reservas dos Termos e Condições de Uso destas Bibliotecas Digitais, disponíveis em https://digitalis.uc.pt/pt-pt/termos.

Conforme exposto nos referidos Termos e Condições de Uso, o descarregamento de títulos de acesso restrito requer uma licença válida de autorização devendo o utilizador aceder ao(s) documento(s) a partir de um endereço de IP da instituição detentora da supramencionada licença.

Ao utilizador é apenas permitido o descarregamento para uso pessoal, pelo que o emprego do(s) título(s) descarregado(s) para outro fim, designadamente comercial, carece de autorização do respetivo autor ou editor da obra.

Na medida em que todas as obras da UC Digitalis se encontram protegidas pelo Código do Direito de Autor e Direitos Conexos e demais legislação aplicável, toda a cópia, parcial ou total, deste documento, nos casos em que é legalmente admitida, deverá conter ou fazer-se acompanhar por este aviso.

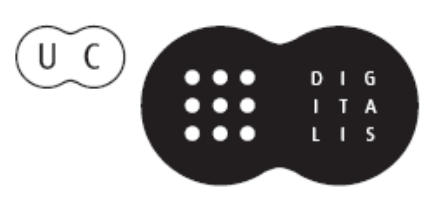




\section{Pólis/Cosmópolis}

\section{Identidades Globais \& Locais}

Carmen Soares, Maria do Céu Fialho \& Thomas Figueira (coords.)

IMPRENSA DA UNIVERSIDADE DE COIMBRA 


\title{
DA Pólis À COSMÓPOLIS: DOS MOSTEIROS CISTERCIENSES portugueses ao Capítulo geral de Cister ${ }^{1}$ (From "Polis" to "Cosmopolis": From Portuguese Cistercian Monasteries to the Cistercian General Chapter)
}

\author{
Maria Alegria Marques (alegriamarques@sapo.pt) \\ Universidade de Coimbra
}

\begin{abstract}
Resumo - A partir da presença das referências aos mosteiros portugueses nas reuniões do capítulo geral de Cister, desde os finais do século XII ao século XIV, estudamos os problemas que eles aí suscitaram e as missões que foram cometidas aos seus representantes, relativamente à vivência das normas, à gestão dos mosteiros e às relações com a sociedade.

Palavras-chave: Ordem de Cister; capítulo geral; mosteiros cistercienses; Cister português.
\end{abstract}

Aвstract - Utilizing the references to the representatives of Portuguese monasteries in the meetings of the General Chapter of Citeaux, from the late twelfth century to the fourteenth century, I examine the issues which they raised there and the missions with which they were charged, in areas such as standards of living, monastery management, and social relations.

Keywords: Cistercian Order, general chapter, Portuguese Cistercian monasteries.

\section{INTRODUÇÃo}

$\mathrm{Na}$ força do ideal ou na letra da norma, um mosteiro beneditino ou, posteriormente, cisterciense, deveria ser a imagem da cidade ideal, dotado de todos os requisitos necessários à vida da comunidade que o habitava. Segundo a regra que lhes servia de matriz, a beneditina, um mosteiro deveria "ser construído de forma a ter de portas a dentro tudo o necessário, a saber: água, moinho, horta, oficinas onde se exerçam os diversos ofícios, para que os monges não tenham necessidade de andar lá por fora, o que não é nada conveniente para as suas almas”² e situar-se longe do mundo e do convívio dos homens, como determinava a normativa de Cister, patente no Exordium Cistercii ${ }^{3}$.

Daí, as determinações próprias para a construção dos parcos edifícios de morada dos monges, oratório, refeitório, casa para hóspedes e para o porteiro ${ }^{4}$,

${ }^{1}$ Pelo que havemos de considerar acerca do capítulo geral de Cister e da sua importância, tendo em conta essencialmente a sua composição, entendemos que o tema teria lugar num Congresso subordinado ao tema Pólis e Cosmopolis, que o Centro de Estudos Clássicos da Universidade de Coimbra houve por bem realizar, e cujo convite de participação muito nos honrou e agradecemos.

${ }^{2}$ Regra do Patriarca S. Bento: 132.

${ }^{3}$ Cf. Nascimento, 1999: 57 e 81.

${ }^{4}$ Nascimento: 57 . 
bem como a indicação daqueles que se podiam situar fora dos muros do mosteiro, entre os quais nenhum para habitação, apenas os destinados aos animais ${ }^{5}$. Tudo, de acordo com um desejo de fuga ao mundo e de mortificação do corpo, na busca de um ideal de purificação, de uma sede de além, de uma união a Cristo.

Se o tópico do deserto, do ermo, foi traço comum dos movimentos de reforma espiritual ao longo dos tempos (já assim o exprimiam as palavras de S. Jerónimo (345-420?), nudos amat eremus), e está bem presente nas diversas tentativas do séc. $\mathrm{XI}^{6}$, foi a experiência cisterciense a sua expressão mais pura e duradoura. Ele dá o sentido profundo de reforma que animava os monges que, em 1198, retirando-se de Molesme, se estabeleceram em Cister. Mas a busca do deserto, do ermo, da solidão, era, ao mesmo tempo, simbólica e real. Era simbólica, enquanto sinal de ruptura total com o mundo e exigência de um sentimento de amor e caridade entre os homens, que os fazia comunicantes pela oração. Era real, quando exigia a busca do isolamento físico dos locais de fixação das comunidades que pretendiam dedicar-se à imitação de Cristo. Ambos se caldeavam com uma vertente mística, na transcendência da realidade e do quotidiano e tornavam-se sonho, volvendo-se em condição de ligação íntima do homem e da natureza, a exemplo de S. Bernardo, que aconselhava o seu amigo Henri Murdach, abade de Vauclair, a procurar, porque encontraria, "mais alguma coisa nas florestas que nos livros" e lhe garantia que "as árvores e os rochedos" lhe ensinariam o que ele "não poderia aprender com nenhum mestre" eremítica, pobreza, em contraponto com a rotina diária, confortável, segura, da vivência dos monges das grandes abadias do séc. XI, particularmente das beneditinas, mas garantia de restauração do princípio da "cidade monástica autónoma", na sua pureza, permitindo, ao monge, a possibilidade da simbiose perfeita da solidão, da pobreza e do trabalho manual ${ }^{9}$.

\section{OS PRINCÍPIOS DA ORGANIZAÇÃo CISTERCIENSE}

Apresentado desta forma, o projecto revela-se sob uma egoísta, quiçá, perigosa independência. Mas assim não foi. Os fundadores da nova observância souberam dotar a sua obra de regras mínimas de organização e convivência, tendentes a fomentar um espírito de fraternidade e a manter uma união. Aliás, elas tornavam-se necessárias, tanto quanto os mosteiros cistercienses rapidamente

${ }^{5}$ Nascimento: 57.

6 "El comúm denominador de todos los esfuerzos reformadores del siglo XI, fue el deseo de establecer una vida heroica de mortificaciones, vivida fuera de toda complicación mundana" (Lekai, 1987: 15).

${ }^{7}$ Pressouyre, 1990 : 30. Sobre o tema, ver também Nascimento, 1999: 7. Sobre a ligação do Santo à natureza, ver a sua vida, em Voragine, 2004: 100.

${ }^{8}$ Pressouyre, 1999: 39.

${ }^{9}$ Pressouyre, 1999: 37-47, sobre a organização espacial e funcional da abadia cisterciense. 
cresceram em membros e em número, pois, como afirma o Pequeno Exórdio, no seu final, "Desde então instalaram abadias em diferentes dioceses. E elas foram crescendo dia a dia pelo efeito de um tão abundante e tão poderosa benção do Senhor que, [em] menos de oito anos, foram construídos doze mosteiros, uns saídos directamente de Cister e os outros provenientes da sua descendência" ${ }^{10}$.

As primeiras normas nesse sentido, foram registadas, por escrito, em 1114 (data da fundação de Pontigny, a primeira das filhas de Cister), tendo-se multiplicado e enriquecido com novos elementos (documentos oficiais relativos aos primórdios da Ordem, estatutos complementares e ainda bulas papais de privilégio), durante a primeira metade do séc. XII ${ }^{11}$.

O documento primitivo, de importância fundamental para a nova Ordem, nasceu ainda em tempo de Santo Estevão Harding, o segundo abade de Cister, e foi denominado, por ele próprio, por Carta de caridade. Nas palavras desse fundador, ele surgia para salvaguardar a "paz recíproca", "a fim de que não haja nenhuma discórdia nos nossos actos, mas que, numa só caridade, numa só regra, vivamos segundo costumes semelhantes" ${ }^{12}$. Verdadeiro instrumento jurídico da Ordem de Cister, procurava, como nele se afirma, "elucidar, estatuir e transmitir (...) um pacto de amizade, por qual modo de vida, ou antes por que tipo de caridade se deviam unir indissoluvelmente em espírito, os seus monges, corporalmente espalhados pelas abadias (...)"13. Por outras palavras, procurava regulamentar alguns aspectos práticos que poderiam concorrer para a concretização do preceito "Não tenhais para com ninguém nenhuma espécie de dívida a não ser a dívida do amor recíproco" 14 .

No essencial, estatuíam-se os aspectos fundamentais da organização que haveriam de dar um aspecto uno e único à Ordem, no seu conjunto: obrigatoriedade de compreensão e observação da regra por todos, de uma única maneira; obrigatoriedade do uso dos mesmos livros litúrgicos e observância dos mesmos usos e costumes em todos os mosteiros. Esta proposta de observância de um mesmo modelo - concebido a partir das normas beneditinas - favorecia a coesão e estabelecia laços orgânicos entre os mosteiros aderentes, que eram todos os que se acolhiam à sombra da nova observância.

Ao mesmo tempo, e porque fundamental a uma Ordem que nasceu de uma cisão, estabeleciam-se minuciosamente as relações jurídicas entre os mosteiros que, entretanto, se fossem multiplicando no seu seio. Este é, na realidade, o verdadeiro elemento inovador na organização institucional cisterciense. Enquanto a regra de $\mathrm{S}$. Bento se centrou na vida no seio do mosteiro, Cister havia de se

\footnotetext{
${ }^{10}$ Os cistercienses: 67.

${ }^{11}$ Pacaut, 1993: 38 e 64.

${ }^{12}$ Pacaut, 1993: 64.

${ }^{13}$ Os cistercienses: 73.

${ }^{14}$ Os cistercienses: 139.
} 
preocupar com a definição das relações entre as casas que se acolhiam ao seu projecto.

O primeiro aspecto que se nos impõe é a própria nomenclatura das abadias, nas suas relações entre si: abadias-mãe e abadias-filha, conforme faziam surgir ou aceitavam na sua dependência e proteç̧ão outras abadias entretanto surgidas por crescimento e vontade das existentes ou por outras vias, desejosas de entrar na nova organização. Assim se criavam laços, se estimulavam elos, se pretendia afastar a discórdia, se ultrapassava a distância e a sujeição.

As normas que haviam de definir os aspectos jurídico-económicos e jurídico-administrativo da organização que se pretendia afirmar e salvaguardar estavam já inculcadas na Carta de Caridade. Quanto aos primeiros, o documento matricial declarava a plena independência material entre as casas da organização, ao estabelecer que nada se imporia sobre bens temporais que pudesse redundar em vantagem para uma e prejuízo para outra. Quanto ao segundo, a sua regulamentação constitui a grande preocupação e a grande aposta dos seus mentores e autores. Por isso, o documento estatuía o quadro de obrigações do abade-pai em relação às suas filhas. Entre elas, destacava-se a visita anual à abadia-filha, talvez a sua obrigação maior, pois que era o modo de assegurar a unanimidade da Ordem, sem intervir na gestão de cada casa em particular ${ }^{15}$, com a necessária regulamentação (precedências, direitos e deveres de visitandos e visitados) ${ }^{16}$. Nas responsabilidades da abadia-mãe, caberia também, aos seus superiores, velar por qualquer abadia-filha em caso de ocorrência de uma qualquer vacância. Bem como lhe competia zelar pela qualidade do abade-filho, na correcção de faltas ou, no limite, na deposição dos incorrigíveis. No primeiro dos casos, cumpria ao abade-pai assumir a responsabilidade da administração da abadia-filha até à eleição de novo abade. Por isso, era também a ele que competia a convocação da eleição, com a chamada de outros abades oriundos da casa-mãe em questão. Todos eles - estes e os monges sem pastor - com o conselho e aprovação do seu abade-pai procediam, então, à eleição de novo abade. Ela tanto podia recair sobre um irmão do mosteiro em causa, como sobre um de qualquer outro mosteiro, mesmo da própria abadia-mãe. No caso, apenas se proibia a escolha de alguém estranho à Ordem ${ }^{17}$. Se a vacância de um mosteiro se anunciava, quando um abade pretendia renunciar ao seu cargo, também aí estava reservado um papel ao abade-pai: competia-lhe ser paciente e conselheiro, não dando facilmente o seu consentimento. Ele só viria depois de um conselho com outros abades da Ordem.

Papel importante lhe ficava ainda, quando, numa abadia-filha, surgia um abade pouco cumpridor, menos responsável. Então, cabia-lhe admoestá-lo ou,

\footnotetext{
${ }^{15}$ Era, digamos, o momento do jogo do equilíbrio de interesses e de objectivos.

${ }^{16} \mathrm{Na}$ lógica do "amor recíproco", própria da tutela parental, igualmente se estabeleciam as regras a respeitar quando se verificasse a visita de um abade-filho a uma abadia-mãe.

${ }^{17}$ Igualmente se proibia a cedência de um irmão para responsável em qualquer outra Ordem.
} 
em caso limite, suspendê-lo mesmo e, caso tivesse apoiantes no próprio mosteiro, lançar também a excomunhão sobre esses membros prevaricadores.

Ainda na busca da unidade se registava a obrigatoriedade da realização de um capítulo geral dos abades dos seus mosteiros ${ }^{18}$, anualmente, em Cister, para "se verem pessoalmente, estreitarem os laços de disciplina da Ordem, reforçarem a paz e conservarem a caridade" ${ }^{19}$. Por isso, eram esse o momento e o local indicados para a "denúncia pública, mas com caridade", dos erros e desvios dos abades, das suas faltas e dos seus litígios. Igualmente, e porque "a caridade é a maior das virtudes” ${ }^{20}$, era também o capítulo o local indicado para a informação sobre a incapacidade económica das abadias, cuja "pobreza intolerável” "todos os abades, inflamados pelo fogo ardente da caridade se apressarão a socorrer, cada um dentro das suas possibilidades" ${ }^{21}$. Na conjugação de ideal e pragmatismo, o capítulo geral concedia a cada abade um lugar de direito, igual para todos, refreando, assim tentações de ingerência de abades-pai.

São estes os principais princípios jurídicos da Ordem cisterciense. Definiam a sua constituição, regulamentavam a administração das casas, na sua gestão e continuidade, estatuíam as relações das diferentes casas entre si. Num grau superior, garantiam a unidade da Ordem ${ }^{22}$. E ainda que com algumas modificações mais ou menos pontuais, surgidas de novos tempos, as grandes linhas desta organização marcaram a vida da Ordem até ao séc. XVI ${ }^{23}$.

Ao mesmo tempo, tais princípios tanto reflectem o mundo em que a reforma cisterciense nasceu, como ofereciam propostas válidas para a própria sociedade, quiçá, mesmo, protótipos para novos tempos. Assim, as relações jurídicas ofereciam um novo modelo, afastado já da hierárquica matriz cluniacense, de relações de subordinação entre vassalos e senhores; antes se pretendia que as suas casas vivessem em capacidade autonómica, embora em união espiritual às outras a que se ligavam por laços de fraternidade. A culminar o seu edifício jurídico-administrativo, a proposta de um capítulo geral, a sua continuidade e funções revelaram-se o elemento mais inovador da ordem de $\mathrm{Cister}^{24}$. Nascido de uma exigência da própria dinâmica e crescimento da Ordem - como poderia ser possível a visitação de tantas abadias, nascidas ou filiadas nas quatro casas

${ }^{18}$ Reconhecido explicitamente desde 1127 como o órgão supremo da Ordem, sob a autoridade do abade de Cister (Pacaut, 1993: 66).

19 "Resumo da Carta de caridade", IV, 1, in Nascimento, 1999: 54.

${ }^{20} \mathrm{~S}$. Paulo, 1. ${ }^{a}$ Carta aos Corintios, 13, 13.

${ }^{21}$ Os cistercienses: 89.

${ }^{22}$ Sobre todos estes aspectos dos tempos primitivos da ordem de Cister, ver Pacaut, 1993: 13-109.

${ }^{23}$ Sobre esses tempos de mudança, quando não crise, ver id., ibid.: 279-307.

${ }^{24} \mathrm{~A}$ existência do capítulo, nas ordens existentes, Cister incluída, tinha um carácter bem diferente; era o paradigma de uma participação dos membros de uma comunidade na questão colectiva e na verificação da adequação de comportamentos pessoais a normas institucionais. 
primeiras, filhas mais velhas de Cister? -, o capítulo geral foi a grande revolução no campo das estruturas político-administrativas da Idade Média ${ }^{25}$. Quando as monarquias se debatiam com questões de poder, ameaçadas pelas pretensões pessoais e particulares de senhores feudais, o capítulo de Cister apresentava-se como uma verdadeira assembleia supra-nacional, experiência primordial de um regime parlamentar, a haver nos reinos em afirmação. Exigindo a participação dos abades de todas as casas cistercienses, tinha o direito de legislar, fosse na inovação de normas, fosse na sua modificação e interpretação. Detinha também poderes administrativos e judiciários, relativamente a qualquer questão e lugar, a qualquer norma e a qualquer membro. Assumiu-se simultaneamente como fonte de direito e instrumento da sua interpretação e aplicação, bem como foi o preventor do dirigismo e da anarquia. Como estrutura supra-nacional, relativamente aos particularismos locais da Europa medieval, ou como estrutura de cúpula da organização cisterciense, na aliança perseguida entre as duas vertentes, o capítulo de Cister tentou uma experiência federativa na Europa, mais ou menos bem sucedida. Além de que, sob a sua égide, em última instância se desenrolaram acções de expansão europeia que marcaram os tempos medievais ${ }^{26}$. Num plano mais comum, ele foi, sem dúvida, a oportunidade para muitos dos seus membros deixarem as suas terras, ultrapassarem fronteiras, conhecerem mundos e gentes, ou, na letra deste Congresso, passarem da polis à cosmopolis. Se mais não fosse, só por isso, a experiência de Cister e do seu capítulo geral, com alguma utopia que os animava, merecia bem um lugar de destaque também no campo das instituições de cultura.

Com alguma titubeação nos primeiros tempos, relativamente à data da sua realização, a sua reunião acabou por consagrar-se a 14 de Setembro, de cada ano, na casa-mãe de Cister. As suas actas chegaram até nós, permitindo um conhecimento apurado dos seus trabalhos, hesitações e determinações ${ }^{27}$.

\section{A presença dos mosteiros portugueses}

Ora, é a singularidade e o individualismo dos mosteiros e das questões portuguesas nesse excepcional fórum da Cristandade que pretendemos aqui

${ }^{25}$ Evidentemente que, ele próprio, haveria de ser vítima do crescimento da Ordem: o seu gigantismo foi factor do seu enfraquecimento e da sua desvalorização ao longo do tempo. Diga-se, a propósito, que entrados em certa decadência já a partir do séc. XIII, em 1514, apenas se lhe apresentaram 18 abades! Contudo, tenha-se em atenção que as casas femininas não participavam no capítulo, por decisão deste, do ano de 1237, pois que há indícios de, primitivamente, as abadessas aí terem tido participação. As suas decisões foram codificadas, em certos momentos; sobre elas, ver Lucet, 1997.

${ }^{26}$ Referimo-nos à actividade das ordens monástico-militares que militaram sob os "Usos de Cister", como o Templo, Calatrava, Alcântara, Avis, Cristo. Tudo isto, para nos cingirmos ao Ocidente, pois que houve também expansionismo europeu para Oriente sob a mesma tutela.

${ }^{27}$ Foram publicadas por Joseph-Marie Canivez, 1933-1941. 
apresentar e que entendemos por matéria local. Em complemento, indicaremos outros elementos, relacionados com as visitações ordenadas pelo capítulo, os quais ajudam a compreender melhor a organização cisterciense, no que ela teve de urdidura de teias e relações entre os seus mosteiros, tornada, assim, obviamente, matéria geral, no entanto secundária, em vista das notícias registadas e, sobretudo, do conhecimento dos seus resultados.

Em vista das premissas enunciadas, seria de se esperar um conjunto de informações que ajudassem, até, a esclarecer alguns dos muitos problemas com que se debate a presença de Cister em Portugal, pelo menos no seu primeiro século de existência. Infelizmente, também não é por aqui que ficamos elucidados; bem ao contrário, nalguns dos seus registos são até maiores as interrogações que se suscitam que os problemas que se resolvem.

De qualquer modo, os registos das suas presenças são um dos sinais de como os mosteiros portugueses participaram do cosmopolitismo que foi apanágio da Ordem de Cister, em exemplo pioneiro da Idade Média.

\subsection{A matéria local}

Ilustremos, então, a presença de portugueses no capítulo geral de Cister. Tenhamos em conta que ia já adiantada a reforma cisterciense quando, em Portugal, algum mosteiro se lhe ligou ${ }^{28}$. Por outro lado, não esqueçamos que, sendo obrigação a presença dos abades, ela só se faria notada quando havia lugar a algo de excepcional, ou quando eles fossem comissionados para qualquer missão especial.

Limitamos a nossa pesquisa até ao ano de 1400, quando se anunciavam novas preocupações no capítulo geral e que se centravam na reforma da Ordem. No entanto, temos consciência de que será importante levar a pesquisa até aos meados do séc. XVI, quando se verificou a cisão entre as casas portuguesas e a grande organização, com a fundação da Congregação de Portugal.

Nos três séculos que nos propomos tratar, contam-se mais de seis dezenas de referências a portugueses, seja em assuntos relacionados com muitos dos seus mosteiros, seja com os seus membros, normalmente os abades. O séc. XIII é, de longe, o mais representado ${ }^{29}$, com mais de meia centena de casos, distribuídos de forma muito irregular pelas suas décadas ${ }^{30}$.

A primeira referência de um problema relacionado com um mosteiro português, levantado no capítulo geral de Cister, remonta a 1190, quando a Ordem já tinha cerca de meia dúzia de décadas de presença em Portugal. A última,

\footnotetext{
${ }^{28}$ Em nossa opinião, o primeiro terá sido S. Cristóvão de Lafões, filiado em Claraval. Ver Marques, 1998: 29-73.

${ }^{29}$ No séc. XII, apenas se colhem três referências e cinco no séc. XIV.

${ }^{30}$ Veja-se a distribuição: 1201-1210: 8; 1211-1220:7; 1221-1230: 9; 1231-1240: 4; 12411250: 3; 1251-1260: 4; 1261-1270: 6; 1271-1280: 8; 1281-1290: 2; 1291-1300: 3.
} 
de 1400, liga-se à necessidade de visitação dos mosteiros portugueses, numa perspectiva mais lata, que englobava a orientação de vida das casas peninsulares de Portugal, Castela e Leão.

Ao longo do tempo considerado, foram muitas as razões da presença de nomes portugueses no registo do capítulo geral. Consideramo-las pelos temas a que se reportam.

\subsubsection{A vivência das normas}

Do que ficou dito, nos registos do capítulo geral percebe-se a vivência da norma, exactamente pela indicação da falta cometida. Sem dúvida, que a matéria que mereceu mais referências foi a ausência ao capítulo, alvo de observações de carácter censório. São nomeados e penalizados os abades portugueses faltosos ou negligentes, são censurados os responsáveis peninsulares ausentes, são justificados os abades da Hispânia, ausentes em tempo de guerra ${ }^{31}$. Porém, os responsáveis e os capitulares eram homens do seu tempo e percebiam que quando a crise se anunciava, havia que procurar-se formas de conjugar a diminuição de despesas com as obrigações estatutárias, tanto mais necessário se as abadias eram muito afastadas de Cister (como as portuguesas), o que significava despesas acrescidas. Então, diminuíam-se obrigações e aplanavam-se as censuras.

Outras referências ligadas ao esquecimento das normas estatutárias de Cister dizem respeito à falta da visitação das abadias-filha, pelos responsáveis da abadia-mãe $e^{32}$, aos problemas relacionados com o acesso ${ }^{33}$ ou a renúncia a cargos ${ }^{34}$, ao desrespeito pelo próprio capítulo e suas determinações ${ }^{35}$.

${ }^{31}$ Em 1197, anotava-se que os abades da Hispânia estavam ausentes por causa da "incursão dos pagãos” e em 1269 por causa dos prejuízos da guerra; Canivez (ed.), 1933: 216-217 e 1935: 70. A primeira referência evoca ainda os ecos da derrota dos cristãos, sobretudo do rei de Castela, face aos muçulmanos, em Alarcos; a segunda referir-se-á a uma década de confrontos entre cristãos e muçulmanos, sobretudo Castela e Leão, que haviam de culminar na conquista de Cádis (1265) e de Múrcia (1266).

${ }^{32}$ Caso do mosteiro de Tarouca (1198); Canivez (ed.), 1933: 228.

${ }^{33}$ Em 1208, percebe-se um problema na eleição do abade de Alcobaça, no qual haveria participação do abade de Bouro, que aspirava à abadia alcobacense. Já em 1237, era a determinação da inquirição sobre o abade de Maceira-Dão, que recebera a abadia de forma irregular, ao que parecia, com a conivência de um certo Fr. Estêvão, que o registo apelida de seu "sócio". Por sua vez, em 1243, era o caso do abade de Osseira, que recebera, indevidamente, a profissão do abade de Alcobaça; Canivez (ed.), 1933: 352 e 1934: 182-183, 265, respectivamente.

${ }^{34} \mathrm{O}$ caso do abade de $\mathrm{S}$. Pedro de Águias que renunciou e cuja renúncia foi indevidamente recebida pelo abade de Claraval; ambos foram castigados no capítulo de 1205; Canivez (ed.), 1933: 316.

${ }^{35}$ É o caso do abade de Moreruela, comissionado para tratar da causa do abade de Santa Maria de Aguiar, desobediente e contumaz (1212), o de Alcobaça, com igual incumbência sobre o de Seiça (1216), e o dos abades de Salzedas e de Alcobaça, que, em 1242, também não informaram o capítulo acerca das causas de que tinham sido comissionados anteriormente. $\mathrm{O}$ caso repete-se, em 1277, de uma forma mais genérica, envolvendo os abades da Hispânia que assim procederem. Esta censura deixa perceber o modo de funcionamento do capítulo: sendo- 
Os aspectos comportamentais, no que tinham de desvio da norma, haviam de assumir um lugar especial nos capítulos. De comum, seriam casos mais ou menos chocantes, que convinha punir, morigerar, até pelo contágio do exemplo que poderiam representar. Cabem, neste ponto, o caso do abade de Aguiar, que "falou" desabridamente e de forma desumana contra o seu antecessor ${ }^{36}$, a "experiência" do abade de Santa Maria de Aguiar, que, para se subtrair ao ofício, se fez monge, na mesa, e um seu monge, abade ${ }^{37}$, a falta do abade de Salzedas, ao ajustar um converso para coabitar com uma nobre mulher ${ }^{38}$, a contumácia de um abade de Tarouca, expulso da sua casa e que vagueava pela Hispânia, com o hábito da Ordem e tendo um mulo, por propriedade ${ }^{39}$, ou, genericamente, excessos de monges ${ }^{40}$ ou abades ${ }^{41}$.

Neste aspecto dos desvios comportamentais, assume particular interesse, pelo seu pitoresco, o acontecimento que envolveu os abades de Seiça e S. Pedro de Águias, em 1217. Hospedados na abadia de Marmoutier ${ }^{42}$, a caminho do capítulo geral, não se contentaram com os alimentos que aí lhes foram oferecidos, cebolas, ovos e salmoura, tendo diligenciado por obter bom peixe no burgo. Com uma ração de pão e vinho, oferecida pelo mosteiro hospedeiro, comeram na vila, à porta, "onde nenhum monge costumava comer". Por qualquer razão, não indicada, os conversos que estavam com eles, foram a pé, à abadia de L'Aumône. Mais se disse que os conversos que estavam com eles cheiravam mal, apesar de não se escusarem a pedir água para lavar as mãos. Como resultado de tudo isto, o capítulo entendeu censurá-los e determinar, como castigo, que, todos, se abstivessem de peixe, por um ano, a não ser em caso de grande necessidade ou enfermidade.

O erro podia ir além da falta pessoal, para se achar presente nas relações entre mosteiros. Era a falha da caridade fraterna que deveria unir todos num só corpo, expressa em situações de abades que se digladiavam pela "pecunia" de membros

- lhe denunciado uma qualquer falta, discutia-se o caso e nomeava-se um ou mais abades para inquirirem e informarem o capítulo, posto o que este tomava as deliberações adequadas, segundo os "Usos da Ordem"; Canivez (ed.), 1933: 392, 454, 1934: 257-258 e 1935: 171.

${ }^{36}$ 1190; Canivez (ed.), 1933: 125. Terá de entender-se que se tratou de alguma veemente censura ou de algo que manchou a memória do anterior abade.

37 1206; Canivez (ed.), 1933: 330.

38 1221; Canivez (ed.), 1934: 4.

39 1221; Canivez (ed.), 1933: 6-7. Para ele, o capítulo mandava aos abades e priores da Ordem que lhe retirassem o hábito e o mulo e o considerassem como excomungado e ex-ordenado.

${ }^{40}$ Por regra, apontam-se os excessos, mas não se concretizam. Assim, o dos monges de Tarouca, em 1204, que chegaram a merecer a intervenção do rei de Portugal (D. Sancho I), que, por eles, escreveu ao abade de Claraval; Canivez (ed.), 1933: 299.

${ }^{41}$ Em 1279, referem-se os "excessos gravíssimos" do abade de Alcobaça, recomendando-se que o abade-pai, na sua visitação, inquirisse a verdade e punisse com a deposição ou outra pena que o caso merecesse; Canivez (ed.), 1935: 191.

${ }^{42}$ Abadia beneditina da diocese de Tours. 
fugitivos de um mosteiro a outro ${ }^{43}$, abades que não se entendiam por questões que nos escapam ${ }^{44}$; abade que denunciava abade por qualquer falta específica ${ }^{45}$.

Numa prova de que o castigo era o sentido da correcção da falta, ou, dito de outra forma, de como o capítulo que castigava era o mesmo que usava de caridade para com os faltosos, em 1281, e a propósito do abade de Alcobaça, acusado de faltas gravíssimas e de dilapidação de bens da sua abadia, castigado no ano anterior, por se opor à visitação, a assembleia considerava que um abade deposto podia ser recuperado, com capacidade de elegibilidade, caso apresentasse méritos para isso ${ }^{46}$.

Por último, numa das expressões maiores do poder do capítulo e de exigência de vivência da norma, assistimos à determinação de realização de visitações em Portugal (e noutros reinos peninsulares), em 1390, 1397 e 1400. Isto é, o capítulo tinha bem presente quer a norma da sua carta fundadora, a charta charitatis, quer a noção do valor que tributava a tal prática.

\subsubsection{Os mosteiros portugueses e a sociedade do tempo}

Mas outros assuntos portugueses foram levados ao capítulo geral de Cister, nestes três séculos que consideramos. São de sentido bem diverso dos anteriores e ajudam à leitura das relações dos mosteiros portugueses com a sociedade do tempo.

São de natureza diversa, desde as intenções de novas fundações em Portugal, fossem ligadas à família real ${ }^{47}$ ou proviessem de iniciativa particular ${ }^{48}$, a

${ }^{43}$ Caso de Maceira-Dão e Valbuena, registado em 1217 e 1218; Canivez (ed.), 1933: 477-478.

${ }^{44}$ Tarouca e Bouro, em 1228; Alcobaça e Carracedo, em 1230-1231; Alcobaça e Espina, em 1241; Estrela e Tarouca, e S. Paulo e Lorvão, em 1278; Bouro e Lorvão, em 1280; Valparaíso e Montederramo, Espina e Santa Maria de Aguiar, em 1291; Canivez (ed.), 1934: 69-70, 90, 238-239; 1935: 177, 181, 202, 256.

${ }^{45}$ Como o abade de Salzedas, castigado pelo capítulo, em 1241, por desenterrar um monge, porque ele tinha consigo uma amante e 60 soldos; Canivez (ed.), 1934: 244.

${ }_{46}$ Tratou-se de D. Pedro Nunes; cf. Gomes, 2000: 27-71.

${ }^{47}$ Em 1227, os abades de Tarouca e Alcobaça eram comissionados para o caso da construção de uma abadia da filha do rei de Portugal, do que deveriam dar informação ao capítulo no ano seguinte; ver Canivez, 1933: 62. Sobre este caso e os seguintes (notas 48 e 49), ver o nosso estudo, já citado supra, n. 28.

${ }^{48}$ Em 1220, o capítulo considerava o pedido do chantre de Lisboa para construir uma abadia, em herdade sua e que fosse filha de Alcobaça. O capítulo comissionava os abades de Osseira, Oya e Melón, para inspeccionarem o local e informarem o próximo capítulo; Canivez (ed.), 1933: 529-530. Tratava-se da fundação do mosteiro de S. Paulo de Almaziva, nos arredores de Coimbra; cf. Santos: 1998. Quatro décadas depois, era o tempo de o capítulo se debruçar sobre o andamento do pedido do chanceler do rei de Portugal, para a fundação de um mosteiro no lugar de Logo de Deus, já inspeccionado pelo abade de Alcobaça. Agora, o capítulo mandava que ele ordenasse o convento, verificasse a suficiência dos bens e a filiação em Alcobaça. Como já afirmámos noutro lugar, esta fundação nunca veria o seu dia. Desconhecendo-se, por completo, onde seria o lugar do seu estabelecimento, hoje, estamos em crer que o nome seria o da própria abadia a fundar e não o do de seu assentamento. Com este nome, havia casas em França e em Itália (Pacaut, 1993: 375). Por último, em 1278, o capítulo comissionava os abades de Maceira e Seiça para inspeccionarem o local onde a nobre senhora Domingas Soares pretendia fundar um 
problemas de mudança do lugar de assentamento das abadias ${ }^{49}$. Igualmente estão presentes questões de dificuldades económicas, como são patentes os problemas com o poder régio. No primeiro caso, o mosteiro de S. Pedro de Águias passava pela "máxima pobreza", em 1216, a ponto de o capítulo entender por bem que o abade de Claraval dele dispusesse segundo a utilidade e a honestidade da Ordem e tentasse restabelecer a boa administração em tal casa.

Se no início do séc. XIII, o rei de Portugal se preocupava com os excessos dos monges de Tarouca, a ponto de ter escrito ao capítulo, em 1209 já as questões entre a Ordem e o rei de Portugal eram de outra natureza. Sem qualquer outra informação, apenas o registo do capítulo desse ano nos diz que tais problemas afligiam muito a Ordem, pelo que a magna reunião entendia por bem que o abade de Cister procurasse pessoa conveniente, do círculo do rei, que o levasse "ao amor e reverência da Ordem”, e, se ele persistisse nas suas atitudes vexatórias, então, o abade deveria denunciá-lo, ao papa ${ }^{50}$.

De bem maior alcance e futuro, foi a resposta do capítulo de 1320 ao pedido do rei de Portugal, de aceitar que a Ordem de Cristo se estabelecesse sob o poder do abade de Alcobaça, tanto mais quanto já se achava incorporada, na Ordem, pelo Sumo Pontífice.

Um outro tema que se nos afigura de interesse maior à ordem de Cister em Portugal, prende-se com o pedido régio registado no ano de $1294^{51}$. O rei desejava fazer um estudo para a Ordem, na diocese de Lisboa ${ }^{52}$, para o qual já teria local escolhido. Na circunstância, o capítulo limitava-se a nomear os abades de Salzedas e S. João de Tarouca, para a respectiva inspeç̧ão e para considerarem a petição, se o achassem capaz.

\subsubsection{Gestão corrente}

Sob este título, englobamos um conjunto variado de assuntos, não específico da ordem de Cister, pois que percorrem todo o meio monástico ou até eclesial. Foram também apresentados ao capítulo geral, pois que importavam a casas da Ordem. Por isso lhe chamamos gestão corrente. Encontram-se pedidos

mosteiro para monjas; Canivez (ed.), 1935: 184.

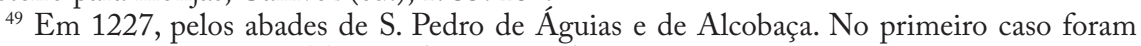
comissionados os abades de Tarouca (abadia-mãe) e Salzedas e, no segundo, os mesmos e o de S. Pedro de Águias; Canivez (ed.), 1934: 63-64.

${ }^{50}$ No fim da vida, D. Sancho I ainda sustentava questões com o clero do reino, particularmente com o bispo do Porto. Na documentação portuguesa, não se rastreia qualquer animosidade entre o rei e os mosteiros de Cister.

${ }^{51}$ Era abade D. Domingos II; cf. Gomes, 2000: 46.

${ }^{52} \mathrm{O}$ documento deveria apresentar qualquer problema de conservação ou leitura, pois que a indicação do local se faz pela expressão "loci ....bonam", sinal de incompletude de leitura paleográfica; Canivez (ed.), 1935: 270. 
de celebração de aniversários por benfeitores, da família real ${ }^{53}$ ou particulares ${ }^{54}$, ou de particular intenção do rei de Portugal ${ }^{55}$. Bem como nos deparamos com a licença para a instituição da festa de Santiago, com a sua história ${ }^{56}$, e a da Santa Coroa, em Alcobaça, em $1263^{57}$.

A existência do capítulo geral, se, por um lado, fazia acorrer, a Cister, os abades de todas as partes da Cristandade, pois que, por elas se espalhou a Ordem, por outro lado, colocava os seus membros sob a alçada dos mais variados riscos. Apesar do longo tempo que abraçamos na nossa análise e das muitas viagens que ele representa, apenas achamos notícia de um caso de violência que atingiu o abade de Salzeda e o de Moreruela, quando se dirigiam ao capítulo, em 1252. Foram roubados e atrozmente feridos, acabando presos, na passagem pela diocese de Blois. Do facto, apresentaram queixa à rainha de França ${ }^{58}$, atitude que foi reiterada pelo capítulo, que a considerou excesso e injúria, bem como cometeu aos abades de Notre-Dame du Val (dioc. Versalhes) e Royaumond (dioc. Beauvais) a atribuição de ajuda nas despesas necessárias.

\section{A matéria geral}

Como anunciámos, sob este título importam aspectos registados nos capítulos sem uma identificação precisa, mas que envolviam casas portuguesas. Relacionam-se com a observância da norma cisterciense, no que dizia respeito

${ }^{53}$ Era o caso da infanta D. Mafalda, falecida em 1256, pedido pelo abade de Salzedas, em 1257, para a sua abadia e para mais duas, de monjas, de que não se menciona o nome, mas de que uma seria Arouca e a outra, talvez, Bouças. Em 1280, foi a hora do pedido de Alcobaça e de Salzedas, pela memória do rei D. Afonso III, falecido no ano anterior; Canivez (ed.), 1934: 431 e 1935: 201.

${ }^{54}$ Foi o caso do abade de Salzedas, que, em 1252, apresentou o pedido da instituição de um aniversário em memória de Miana Teresa, fundadora da abadia. Trata-se de D. Teresa Afonso, mulher de Egas Moniz. É muito curioso verificar este pedido tão tardio; de qualquer modo, ele representa a presença bem viva, da sua memória no mosteiro. Em 1294, foi a vez de o bispo de Lisboa, D. João Martins de Soalhães, apresentar, ao capítulo, o seu pedido de instituição de um aniversário no mosteiro de Alcobaça, obtida a concordância do convento; Canivez (ed.), 1934: 379 e 1935: 275, respectivamente.

55 Assim entendemos o pedido apresentado em 1344, de duas missas, uma do Espírito Santo, outra da Virgem Santa, em cada uma das casas da Ordem. Talvez que o rei se encontrasse bastante doente, pois que viria a falecer em 28 de Maio de 1357; Canivez (ed.), 1935: 500.

${ }^{56}$ Canivez (ed.), 1935:13. Esta indicação leva-nos a aceitar a hipótese de estarmos perante qualquer representação teatral.

${ }^{57}$ Id., ibid.; esta festa liga-se ao culto das relíquias, tão em voga na Idade Média. Concretamente, trata-se das relíquias da Coroa de espinhos, compradas por S. Luís ao imperador Balduíno II de Constantinopla, por intermédio de um veneziano, em 1239, e para a qual mandou construir a Sainte Chapelle (1248); no intervalo, a relíquia ficou no palácio, no altar de S. Nicolau. (Muito penhorada, agradecemos esta informação ao Senhor Professor Doutor Aires Nascimento).

${ }^{58}$ Deve ser referência a Branca de Castela, mãe de Luís IX, que faleceria em 27 de Novembro de 1252, em Melun. 
à importante prática da visitação e à participação em acções expressamente comissionadas pelo capítulo. Parecem-nos determinações importantes, pois que colocavam em acção e, sobretudo, em contacto, membros portugueses da Ordem com outras casas, noutras paragens, sobretudo em Leão e Castela, e permitiam a presença de membros estrangeiros, especialmente peninsulares, em Portugal.

Relativamente a abades, casas ou questões portuguesas, ao longo do tempo encontramos comissionados ${ }^{59}$ os abades de Sacramenia (1), Huerta (2), La Espina (6), Osseira (5), Armenteira (1), Melón (3), Moreruela (3), Sobrado (1), Oia (2), Montederamo (1), Meira (1), Sandoval (1), Valbuena (1) e Valdeiglesias (1). Ao invés, apenas os responsáveis de Aguiar e de Fiães foram chamados a intervir em questões relacionadas com agentes ou instituições de além-fronteiras, mas sempre peninsulares ${ }^{60}$. Sem percebermos como se fazia a nomeação, mesmo assim arriscamos que haveria um qualquer factor pessoal, a interferir na escolha ${ }^{61}$.

Estas intervenções revelam-se bem desiguais. Ora se tratava apenas de comunicar a resolução do capítulo acerca de certa questão ou situação, normalmente censuras por faltas cometidas, ora se tratava de tentar resolver qualquer conflito nascido entre dignitários ou instituições, por vezes de espaços políticos diferentes ${ }^{62}$.

No primeiro século da existência de Cister, encontramos ainda o apelo a Cister e a Claraval, relativamente a questões portuguesas. Ou porque houvera resignação injustificada, ou porque o rei de Portugal se intrometia, indevidamente, nos assuntos das casas monásticas, ou porque algum mosteiro se achava em extrema pobreza, afinal questões de cumprimento das normas, exercício de política ou da caridade fraterna.

Decorrentes ainda dos capítulos, provinham as visitações, como afirmámos momentos excepcionais na vida dos mosteiros cistercienses, pelo que representavam de união entre si. De um modo geral, bem aceites, porque das normas da Ordem, não se acha qualquer acta para o tempo sobre o qual nos debruçamos ${ }^{63}$, embora haja prova da sua realização ${ }^{64}$.

${ }^{59}$ Entre ( ), indicamos as vezes que o foram.

${ }^{60}$ Ou relativos aos abades da Hispânia (1197) ou a Leão e Castela.

${ }^{61}$ É o que se nos sugere o caso do abade de Fiães, que, em 1242, é nomeado para três casos; Canivez (ed.), 1934: 257-258.

${ }^{62}$ Por exemplo, em 1217 e 1218, entre Maceira-Dão e Valbuena; em 1230, entre Alcobaça e Carracedo; em 1291, entre os abades de Valparaíso, Montederramo e Santa Maria de Aguiar; cfr. supra, notas 44 e 45.

${ }^{63}$ Sobre este tema, ver Gomes, 1998.

${ }^{64}$ Em Marques, 1998: 73-88, publicamos um documento de 13 de Dezembro de 1381, no mosteiro de Salzeda, pelo qual o abade do mosteiro de S. Pedro das Águias, comissionado para a causa da eleição de Fr. João Dornelas como abade de Alcobaça, por comissão de Fr. João de Chassagnollis, mandatário do abade de Claraval para a visitação aos mosteiros cistercienses nos 


\section{Conclusão}

Nos cerca de três séculos de existência de Cister em Portugal, que agora percorremos, foram estes os aspectos salientes que os representantes portugueses de Cister levaram às reuniões do capítulo geral da sua Ordem ou aí viram propostos, para discussão e determinação. $\mathrm{Na}$ sua essência, não diferiam dos que outros mosteiros, de outras partes da Cristandade, viram tratados nesse areópago da Ordem. Nas suas misérias e nas suas grandezas, todos se irmanavam no espírito e nas práticas da Ordem.

A comunhão dos representantes das casas portuguesas, nas suas faltas e petições, com os de outras casas da Ordem, dos locais mais próximos, Galiza ou Leão e Castela, ou aos mais longínquos, fazia-os participar de um espírito e de uma visão cosmopolista que só a Ordem de Cister soube imprimir à sua organização. É certo que não sabemos até que ponto chegou essa comunhão. Mas estamos em crer que muito da cultura que se bebeu nos mosteiros portugueses, Alcobaça à sua cabeça, teve a sua origem ou, pelo menos, o seu anúncio em muitos desses encontros, como momentos privilegiados de troca de experiências, de recepção de novidades do tempo e aquisição de repertórios culturais ${ }^{65}$.

Quanto à documentação percorrida, fica demonstrado que, embora não dê muitas das respostas desejáveis e necessárias à elucidação de problemas da Ordem de Cister em Portugal, ela não pode e não deve ser descurada em estudos sobre as instituições cistercienses portuguesas; se questiona, também pode ajudar a esclarecer e, sobretudo, a complementar, a que perdurou em Portugal.

E esta nota é tanto mais de realçar, quanto o grande movimento monástico precedente, o cluniacense, apesar da sua grande influência cultural inicial em Portugal, a exemplo da Península, não proporcionou assinalável influxo por parte da própria congregação de Cluny ${ }^{66}$.

reinos da Península, entre os quais Portugal, dá conta de todo o processo. Por documento incluso no mesmo, de 9 de Junho desse mesmo ano, em Guimarães, Fr. João de Chassignollis fez saber que visitou os mosteiros portugueses sujeitos a Claraval, como lhe fora ordenado, e que delegava os seus poderes de visitador, na sua ausência, nos abades de S. Pedro das Águias e de Torre de Aguiar.

${ }^{65}$ Sobre esta matéria, ver a muita bibliografia de Aires Nascimento. Entretanto, o caso fica bem ilustrado com o que acima se diz acerca da festa da Santa Coroa.

${ }^{66} \mathrm{Na}$ realidade, também não teria condições para tal, uma vez que só tinha vinculadas, a si, três casas portuguesas e sem grande expressão: os priorados de S. Pedro de Rates (1100), Santa Justa de Coimbra (1102), e de Vimieiro (1127), que haviam de fazer parte da "camararia" da Galiza. 


\section{Bibliografia Final}

AA.VV. (1990), Archéologie de la vigne et du vin. Actes du colloque 28-29 mai 1988, Paris.

AA.VV. (1992), Archeologia del paesaggio. IV Ciclo di lezioni sulla ricerca applicata in archeologia, Certosa di Pontignano (Siena) 14 - 26 gennaio 1991, Firenze.

AA.VV. (1997), Uomo, acqua e paesaggio. Atti dell'incontro di studio sul tema irreggimentazione delle acque e trasformazione del paesaggio antico, S. Maria Capua Vetere 22 - 23 novembre 1996, Roma.

AA.VV. (1998), El vi a l'antiguitat. Economia, producció i comerç al Mediterrani occidental. II Colloqui internacional d'arqueologia romana. Actes. Badalona, 6 - 9 de maig de 1998, Badalona.

AA.VV. (1999), El vino en la antigüedad romana. Simposio arqueología del vino, Jérez 2, 3 y 4 de octubre 1996, Madrid.

AA.VV. (1999b), Environmental reconstruction in Mediterranean landscape archaeology, Oxford.

AA.VV. (2001), La cerveza en la antigüedad, Sevilla.

AA.VV. (2004), Le vin. Nectar des dieux, génie des hommes, Gollion.

Abascal, J. Manuel, Espinosa, Urbano (1989), La ciudad hispano-romana. Privilegio y poder, Logronho.

Abásolo, J. A., Mayer, M. (1997), "Inscripciones latinas”, in S. Corchón (coord.), La Cueva de la Griega de Pedraza (Segovia), Zamora, 183-259.

Abbondanza, L. (ed.) (2008), Filostrato Maggiore, Milano.

Acosta-Hughes, B. (2002), Polyeideia. The Iambi of Callimachus and the Archaic Iambic Tradition, Berkeley and Los Angeles.

Adams, C. (2001), "There and back again. Getting around in Roman Egypt", in Adams, C. and R. Laurence (eds.), Travel and Geography in the Roman Empire, Londres and Nova Iorque, 138-166.

Adams, J. N. (2003), Bilingualism and the Latin language, Cambridge.

Adams, J. N. (2003a), “Romanitas and the Latin language”, CQ 53: 184-205.

Affatato, R. (2010), "Nueva York: recepción del mito de la ciudad en Federico García Lorca e Italo Calvino", in J. M. Losada Goya (ed.), Mito y mundo contemporáneo. La recepción de los mitos antiguos, medievales y modernos en la literatura contemporánea, Bari, 627-640.

Albuquerque, M. de (1968), O poder politico no Renascimento português, Lisboa.

Albuquerque, M. de (1981), "Bártolo e bartolismo na história do direito português”, Boletim do Ministério da Justiça 304: 41-61.

Albuquerque, M. de (1983), Estudos de cultura portuguesa, I, Lisboa. 
Alexandrescu-Vianu, M. (1988), “O nouă posibilă genealogie a familiei lui Hippolochos, fiul lui Theodotod, de la Histria”, SCIVA 39.3: 275-280.

Alexandrescu-Vianu, M. (1989), "Apollon Ietros. Ein verschollener Gott Ioniens?”, IstMitt 39: 115-122.

Alexandrescu-Vianu, M. (1990), "Die Steinskulptur von Histria", in P. Alexandrescu, W. Schuller (eds.) Histria. Eine Griechenstadt an der rumänischen Schwarzmeerkünste, Xenia. Konstanzer Althistorische Vorträge und Forschungen 25, Konstanz, 179-232.

Alexandrescu-Vianu, M. (2000), "Une alternative d'identification de la statue colossale d'Istros", in A. Avram, M. Babeş (eds.) Civilsation grecque et cultures antiques périphériques. Hommages à $P$. Alexandrescu à son $70^{\circ}$ anniversaire, Bucarest, 274-281.

Alexandridis, A. (2004), Die Frauen des römischen Kaiserhauses. Eine Untersuchung ibrer bildlichen Darstellung von Livia bis Iulia Domna, Mainz.

Alfayé, S., Marco, F. (2008), "Religion, language and identity in Hispania: Celtiberian and Lusitanian rock inscriptions", in R. Häußler (ed.), Romanisation et épigraphie. Etudes interdisciplinaires sur lacculturation et lidentité dans l,Empire romain, Montagne.

Alföldi, A. (1948), The conversion of Constantine and Pagan Rome, Oxford.

Alföldy, G. (1969), Fasti Hispanienses, Wiesbaden.

Alföldy, G. (1973), Flamines provinciae Hispaniae citerioris, Madrid.

Alföldy, G. (1991), "Augustus und die Inschriften: Tradition und Innovation. Die Geburt der imperialen Epigraphik”, Gymnasium 98: 289-324.

Allen, A. (1951), History of political thought in the sixteenth century. London

Altaner, B., Stuiber, A. (2a ed. 1972), Patrologia, São Paulo.

Amouretti, M.C., Brun J.-P. (eds.) (1993), La production du vin et de l'buile en Méditerranée. Actes du symposium international organisé par le Centre Camille Jullian et le Centre archéologique du Var, Aix-en-Provence et Toulon 20-22 novembre 1991 (BCH suppl. 26), Athènes.

Ando, C. (2003), "A Religion for the Empire", in A. J. Boyle, W. J. Dominik (eds.), Flavian Rome. Culture, Image, Text, Leiden, Boston 323-344.

Ando, C. (2006), "Interpretatio Romana”, in L. de Blois, P. Funke, J. Hahn, (eds.), The Impact of Imperial Rome on Religions, Ritual and Religious Life in the Roman Empire, Proceedings of the Fifth Workshop of the International Network Impact of Empire (Roman Empire 200 B.C. - A.D. 476.), Leiden, Boston 51-65.

Andrade, A. A. (1959), S. Tomás de Aquino no periodo áureo da filosofia portuguesa, Lisboa.

Andrade, A. A. de (1965), Antologia do pensamento politico português (séc. XVI), vol. I. Lisboa. 
Andrade, M. (1974), "Lira Paulistana”, in Poesias completas, São Paulo.

Andreu, J. (2004), Edictum, Municipium y Lex: Hispania en época flavia (69-96 d. C.), BAR Int. Ser. 1293, Oxford.

Antonietti, C. (1999), "Megara e le sue colonie: unità storico-culturale?”, in C. Antonetti, P. Lévêque (eds.) Il dinamismo della colonizzazione greca, Atti della tavola rotonda "Espansione e colonizzazione greca di età arcaica: metodologie e problemi a confront", Venezia, 10-11/11, Besançon-Paris, 17-24.

Aquino, T. de (1946), Des lois de Saint Thomas d'Aquin. Texte traduit et présenté par J. de la Croix Kaelin O. P., Paris.

Arnaldi, A. (2010), “Osservazioni sul flaminato dei Divi nelle provincie africane”, in M. Milanese, P. Ruggeri, C. Vismara, (eds.), L'Africa romana. Luoghi e le forme dei mestieri e della produzione nelle provincie africane. Atti del XVIII convegno di studio. Olbia 11-14 dicembre 2008, vol. III, Roma, 1645-1665.

Arruda, A. M. (2005), "O 10 milénio a.n.e. no Centro e no Sul de Portugal: leituras possíveis no início de um novo século", O Arqueólogo Português Série IV: 23: 59-74.

Arzone, A. (2011), “Alcune considerazioni sulle immagini di pietre miliari e sui riferimenti alle strade nel documento monetale", in I miliari lungo le strade dell'Impero. Caselle di Somma campagna Verona, 77-92.

Asensi, R. M., Musso, O. (1990), "Un documento etrusco di Tarragona", Quaderni della sezione di Studi Storici Alberto Boscolo 1: 5-11.

Aston, M. (1997), Interpreting the landscape. Landscape archaeology and local bistory, London.

$A T L=$ B.D. Meritt, WadeGery, H.T., McGregor, M.F., The Athenian Tribute Lists, 4 vs, Princeton.

Aubert, J.-M. (1955), Le droit romain dans l'oeuvre de Saint Thomas, Paris.

Avery, H. C. (1971), "Euripides' Heraclidae", AJPh 92: 539-565.

Avram, A., Lefèvre, F. (1995), "Les cultes de Callatis et l'oracle de Delphes", REG 108: 7-23.

Bacchielli, L. (1986), "Monumenti funerari a forma di cupula: origine e diffusione in Italia meridionale", in A. Mastino (ed.), L' Africa Romana: atti del 3. convegno di studio Sassari 13-15 dicembre 1985, Sassari, 303-319.

Bailly, A. (1963), Dictionnaire grec-français, Paris.

Balass, G. (s.d.), "The Female Breast as a Source of Charity: Artistic Depictions of Caritas Romana", www.Academia.edu/4006836.

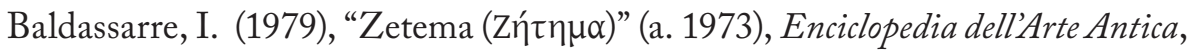
Suppl. 1979: 944-945.

Baldassarre, I., Bragantini, I., Morselli, C. and Taglietti, F. (1996), Necropoli di Porto. Isola Sacra, Roma. 
Balil, A. (1984-88), "Las cupae de Barcino. Contribución al estudio de un tipo de monumento funerario romano", Arqueologia e Historia: 111-115.

Baratta, G. (1993), “Una divinità gallo-romana. Sucellus. Un’ipotesi interpretativa”, ArchCl 45: 233-247.

Baratta, G. (1994), "Circa Alpes ligneis vasis condunt circulisque cingunt", ArchClass 46: 232-260.

Baratta, G. (1997), "Le botti: dati e questioni”, in Techniques et économie antique et médiévale. Le temps de l'innovation. Colloque international, Aix-enProvence 21-23 Mai 1997, Paris, 109-112.

Baratta, G. (1997), "Sucellus", in Enciclopedia dell'Arte Antica classica e orientale, Supplemento 1991-1994, V, Roma, 482.

Baratta, G. (2005a), "La cupa nell'ambito femminile: dalla caupona al loculus?”, in, F. Cenerini, A. Buonopane (eds.), Donna e vita cittadina nella documentazione epigrafica, 95-108.

Baratta, G. (2005b), Römische Kelteranlagen auf der italienischen Halbinsel. Ein Überblick über die schriftlichen, bildlichen und archäologischen Quellen (200 v.Chr. - 400. n.Chr.) (Cornucopia, 11), Murcia.

Baratta, G. (2005c), “Appunti sulle variabili e costanti dell' interpretatio religiosa nell'occidente romano, in F. de Oliveira, (ed.), Génese e consolidação da Ideia de Europa, vol.III, O Mundo Romano, Coimbra, 123-134

Baratta, G. (2006a), "Alcune osservazioni sulla genesi e la diffusione delle cupae", in Atti del XVI Convegno internazionale de L'Africa Romana (Rabat, 15-19 dicembre 2004), Roma, 355-368.

Baratta, G. (2006b), "Nuovi dati sull'iconografia delle mandorle nei sarcofagi strigilati. Un primo approccio ad un corpus", Annali della Facoltà di Lettere e Filosofia dell'Università di Macerata 26: 65-120.

Baratta, G. (2007), "La mandorla centrale dei sarcofagi strigilati. Un campo iconografico ed i suoi simboli", in F. Hoelscher, T. Hoelscher (eds.), Römische Bilderwelten. Von der Wirklichkeit zum Bild und zurück. Kolloquium der Gerda Henkel Stiftung am Deutschen Archäologischen Institut Rom, Heidelberg, 191-215.

Baron, H. (1938), "Cicero and the Roman civic spirit in the Middle Ages and the Early Renaissance", Bulletin of the John Rylands Library 22: 84-89.

Baron, H. (1970), La crisi del primo Rinascimento italiano, Firenze.

Barresi, P. (2007), "Il sofista Flavio Damiano di Efeso e la costruzione di termeginnasi nell'Asia Minore romana di età imperiale", in O. D. Cordovana, M. Galli, (eds.), Arte e memoria culturale nell'età della Seconda Sofistica, Catania, 137-151.

Barros, J. de (1919), Geografia d'Entre Douro e Minho e Trás-os-Montes, Porto. 
Barros, J. de (1937), Panegíricos - Panegírico de D. João III e da Infanta D. Maria, Texto restituído, prefácio e notas por M. Rodrigues Lapa, Lisboa.

Bassignano, M.S. (1974), I faminato nelle provincie romane dell'Africa, Roma.

Bastos, E. (1991), Entre o escândalo e o sucesso. A semana de 22 e o Armory show, Campinas.

Battaglia, M. (2003), "Il Vulcano dei Germani in Giulio Cesare (B.G. VI, 21, 1). Un caso di interpretatio?", Athenaeum 91: 373-401.

Beagon, M. (2005), The Elder Pliny on the Human Animal: Natural History Book 7, Oxford.

Beard, M., North, J., Price, S. (1998), Religions of Rome, vol. I, A History, Cambridge.

Behr, C.A. (ed.) (1973), Aristides, vol. I, Panathenaic Oration in Defence of Oratory, London.

Behrends, M. et alii (eds.) (2000), Hygin. L'oeuvre gromatique, Luxemburg.

Bejarano Osorio, A. M. (1996), "Sepulturas de incineración en la necrópolis oriental de Mérida: las variantes de cupae monolíticas", Anas 9: 37-58.

Belmonte, J. A. (2010), "Documentación fenicio-púnica en la Península Ibérica: estado de la cuestión", in G. Carrasco y J. C. Oliva (eds.), El Mediterráneo antiguo: lenguas y escrituras, Cuenca, 159-220.

Beltrán, F. ed. (1995), Roma y el nacimiento de la cultura epigráfica en occidente, Zaragoza.

Beltrán, F. (2000), "La vida en la frontera", in F. Beltrán, M. Martín-Bueno y F. Pina, Roma en la Cuenca Media del Ebro. La romanización en Aragón, Zaragoza.

Beltrán, F. (2002), "Identidad cívica y adhesión al príncipe en las emisiones municipales hispanas", in F. Marco, F. Pina y J. Remesal (eds.), Religión y propaganda politica en el mundo romano, Barcelona, 159-187.

Beltrán, F. (2004), "E1 latín en la Hispania romana: una perspectiva histórica", in R. Cano (ed.), Historia de la lengua española, Barcelona, 83-106.

Beltrán, F. (2004a), "Nos Celtis genitos et ex Hiberis. Apuntes sobre las identidades colectivas en Celtiberia", in G. Cruz Andreotti y B. Mora Serrano (eds.), Identidades étnicas - Identidades políticas en el mundo prerromano hispano, Kronion 1, Málaga, 87-145.

Beltrán, F. (2004b), “De nuevo sobre la tésera Froehner", Palaeohispanica 4: 4565.

Beltrán, F. (2004c), "Imagen y escritura en la moneda hispánica", in F. Chaves y F. J. García (eds.), Moneta qua scripta. La moneda como soporte de la escritura. Actas del III Encuentro Peninsular de Numismática Antigua, Anejos de AEspA 33: 125-139. 
Beltrán, F. (2004d), "Libertos y cultura epigráfica en la Hispania republicana", in F. Marco, F. Pina y J. Remesal (eds.), Vivir en tierra extraña: emigración e integración cultural en el mundo antiguo, Barcelona, 151-175.

Beltrán, F. (2005), "Cultura escrita, epigrafía y ciudad en el ámbito paleohispánico", Palaeohispanica 5: 21-56.

Beltrán, F. (2006), "Hispania y el Mediterráneo en los siglos II y I a. E.: diversidad cultural y movilidad social", in F. de Oliveira, P. Thiercy, R. Vilaça (eds.), O mar greco-latino, Coimbra, 223-240.

Beltrán, F. (2009), "Vltra eos palos. Una nueva lectura de la línea 7 de la Tabula Contrebiensis", in Espacios, usos y formas de la epigrafía hispana en épocas antigua y tardoantigua. Homenaje al Dr. Armin U. Stylow, Anejos de AEspA 48: 33-42.

Beltrán, F. (2011), "Lengua e identidad en la Hispania romana”, Palaeohispanica 11:19-59.

Beltrán, F. (2011a), “Firmas de artesano o sedes de asociaciones comerciales? A propósito de los epígrafes musivos de Caminreal (E.7.1), Andelo (K.28.1) y E1 Burgo de Ebro (HEp 11, 2001, 621 = AE 2001, 1237)", in E. Luján y J. M. García Alonso (eds.), A Greek man in the Iberian street. Papers in Linguistics and Epigraphy in honour of Javier de Hoz. Innsbrucker Beiträge zur Sprachwissenschaft 140, Innsbruck, 139-147.

Beltrán, F. (2011b), “Les colonies latines d'Hispanie (IIe siècle av. E.): émigration italique et intégration politique", in N. Barrandon y F. Kirbihler (eds.), Les gouverneurs et les provinciaux sous la République romaine, Rennes, 131-144.

Beltrán, F. (2012), "Roma y la epigrafía ibérica sobre piedra del nordeste peninsular", Palaeohispanica 12: 9-30.

Beltrán, F. (inédito), "Diversidad cultural y epigrafía: el ejemplo de Hispania", XII Congressus Internationalis epigraphiae Graecae et Latinae, Barcelona septiembre de 2002.

Beltrán, F., Estarán, M. J. (2011), “Comunicación epigráfica e inscripciones bilingües en la Península Ibérica”, in C. Ruiz Darasse y E. Luján (eds.), Contacts lingüistiques dans l'Occident méditerranéen antique. Collection de la Casa de Velázquez (126), Madrid, 9-25.

Beltrán, F., Velaza, J. (2009), "De etnias y monedas: las "cecas vasconas", una revisión crítica", in J. Andreu (ed.), Los vascones de las fuentes antiguas: en torno a una etnia de la antigüedad peninsular, Barcelona, 99-126.

Beltrán, F., Arasa, F. (1979-1980), "Los itineraria privata en la epigrafía latina”, Historia Antiqua, 9-10: 7-29.

Beltrán, F., Jordán, C., Marco, F. (2005), "Novedades epigráficas en Peñalba de Villastar (Teruel)", Palaeohispanica 5: 911-956.

Bentley, J. H. (1978), Politics and culture in Renaissance Naples, Princeton. 
Berciu, I.,Wolski, W. (1970), "Un nouveau type de tombe mise au jour à Apulum et le problème des sarcophages à voûte de l'Empire romain”, Latomus 29: 919-965.

Bergmann, M. (1998), Die Strablen der Herrscher. Theomorphes und politische Symbolik im Hellenismus und in der römischen Kaiserzeit, Mainz.

Berruti, V., Magistà, A. (eds.) (2009), L'automobile. Marche e modelli dalle origini a oggi, vol. 6, Lancia, Roma.

Besnier M., Chapot, V. (1913), "Via”, Dictionnaire des Antiquités Grecques et Romaines, 5, Paris, 777-817.

Bettini, C. (2008), “Tre Valascos nell'Italia del quatrocento: Meser Valasco di Vespasiano da Bisticci, Petrus Vallascis di Cataldo Siculo e Vasco Fernandes de Lucena", Humanitas 60: 205-226.

Bettini, M., Boldrini, M., Calabrese, O., Piccinni, G. (eds.) (2010), Miti di città, Siena.

Binsfeld, W. (1979), "Zu treverischen Kultdenkmälern”, in Festschrift 100 Jahre Rheinisches Landesmuseum Trier. Beiträge zur Archäologie und Kunst des Trierer Landes, Mainz, 263-269.

Blackman, D. (1969), "The Athenian Navy and Allied Naval Contributions in the Pentecontaetia", GRBS 10: 179-216.

Blanco Freijeiro, A. (1977), El puente de Alcántara en su contexto historico, Madrid.

Boardman, J. (1986), I Greci sui Mari. Traffici e Colonie, Trad. ital., Firenze, Giunti.

Boffo, L. (1975), "Cimone e gli alleatidi Atene”, RIL 109: 442-50.

Bol, R. (1984). Das Statuen programm des Herodes-Atticus-Nymphäums, Berlin.

Bona, G. (ed.) (1988), Pindaro. I peani, Cuneo.

Bonfante, G., Bonfante, L. (2002), The Etruscan language. An introduction. Revised edition, Manchester and New York.

Bonneville, J.-N. (1981), "Les cupae de Barcelone: les origines du type monumental", $M C V 17$ : 5-38.

Bontems, C. (1965), Le prince dans la France des XVIe e XVIIe siècles, Paris.

Bordenache, G. (1960), "Antichità greche e romane nel nuovo Museo di Mangalia”, Dacia N. S. 4: 489-509.

Bordenache, G. (1961), "Histria alla luce del suo materiale scultureo”, Dacia N. S., 185-211.fig. 16.

Bordenache, G. (1969), Sculture greche e romane del Museo Nazionale di Antichità di Bucarest I. Statue e rilievi di culto, elementi architectonici e decorativi, Bukarest.

Boschung, D. (1993a), Die Bildnisse des Augustus, Berlin. 
Boschung, D. (1993b), “Die Bildungstypen der julisch-claudischen Kaiserfamilie: ein kritischer Forschungsbericht", JRA 6: 39-79

Boschung, D. (2002), Gens Augusta. Untersuchungen zu Aufstellung, Wirkung und Bedeutung der Statuengruppen des julisch-claudischen Kaiserbauses, Mainz.

Boucher, S. (1987), "Limage et les fonctions du dieu Sucellus", Caesarodunum 23: 77-85.

Boulanger, A. (1923), Aelius Aristide et la sophistique dans la province d'Asie au II siècle de notre ère, Paris.

Bowersock, G.W. (1969), Greek Sophists in the Roman Empire, Oxford.

Braancamp Freire A. (ed.) (1916), Notícias da Vida de André de Resende pelo Beneficiado Francisco Leitão Ferreira, Lisboa.

Bracco, V. (1985), "Il tabellarius di Polla", Epigraphica 47: 93-97.

Brandão, M. (1937), Documentos de D. João III, I, Coimbra.

Brandt, H. (1998), Geschichte der römischer Kaiserzeit. Von Diokletian und Konstantin bis zum Ende der konstantinische Dynastie (264-363), Berlin.

Briant, P. (2002), From Cyrus to Alexander. A History of the Persian Empire, Winona Lake.

Brown, B.R. (1957), Ptolemaic Paintings and Mosaics and the Alexandrian style, Cambridge.

Brown, T. S. (1946), "Euhemerus and the Historians", HThR 39: 259-274.

Brun, J.-P. (1986), L'oléiculture antique en Provence. Les huiliers du departement du Var (RANArb suppl. 15), Paris.

Brun, J.-P. (2003), Le vin et l'huile dans la Méditerranée antique. Viticulture, oléiculture et procédés de transformation, Paris.

Brun, J.-P. (2004), Archéologie du vin et de l'huile dans l'empire romain, Paris.

Brun, J.-P. (2005), Archéologie du vin et d'buile en Gaule romaine, Paris.

Bruneau, P. (1985), "Deliaca. Iconographie. L'image de Delos personifiée e pyxides de Spina”, BCH 109: 551-556.

Búa, C. (1997), "Dialectos indoeuropeos na franxa ocidental hispânica”, in G. Pereira (ed.), Galicia fai dous mil anos. O feito diferencial galego, volumen I. Historia, Santiago de Compostela, 51-99.

Buck, R. J. (1979), A History of Boeotia, Edmonton.

Bulloch, A. W (1985), Callimachus. The Fifth Hymn, Cambridge.

Bulloch, A. W (2010), "Hymns and Encomia", in J. J Clauss and M. Cuypers (eds.), A Companion to Hellenistic Literature, Malden/Oxford, 166-180.

Burazacchini, G. (ed.) (2005), Troia tra realtà e legenda, Parma.

Burckhardt J. (1949), The Age of Constantine the Great, Berkeley. 
Burke, P. (1987 3a ed.), The italian Renaissance culture and society in Italy, Cambridge.

Burkert, W. (1991), Mito e Mitologia, Ed. 70, Lisboa.

Burkhalter-Arce, F. (2002), "Le tarif de Coptos". La douane de Coptos, les fermiers de l'apostolion et le préfet du desert de Bérénice”, Topoi Supp. 3: 199-233.

Burnett, A. P. (2005), Pindar's Songs for Young Athletes of Aigina, Oxford.

Bury, J. B., Cook, S. A., Adcock ,F. E. (eds.), The Cambridge Ancient History, Vol. 4, Cambridge.

Butcher, K. (2003), Roman Syria and the Near East, London.

Buxton, R. (ed.) (1999), From Myth to Reason? Studies in the Development of Greek Thought, Oxford.

Caccamo Caltabiano, M. (2003), "Messana/Tyche sulle monete della città dello stretto", in Archeologia del Mediterraneo. Studi in onore di Ernesto De Miro, Roma, 139-149.

Cadotte, A. (2007), La romanisation des dieux. L'interpretatio romana en Afrique du Nord sous le Haut-Empire (Religions in the Graeco-Roman world 158), Leiden.

Caiado, H. (1745), Eclogae et Sylvae et Epigrammata, in Pe. A. dos Reis, Corpus illustrium poetarum Lusitanorum, qui latine scripserunt, Lisboa.

Cairns, D. L. (2010), Bacchylides: five epinician odes (3, 5, 9, 11, 13), Cambridge.

Camia, F. (2011), Theoi sebastoi. Il culto degli imperatori romani in Grecia (provincia Achaia) nel secondo secolo D.C., Athinai.

Caldera de Castro, M. D. P. (1978), "Una sepultura de cupa hallada en Mérida. (Consideraciones acerca de estos monumentos funerarios)", Habis 9: 455-463.

Calderón Dorda, E., De Lazzer, A., Pellizer, E., (eds.) (2003), Corpus Plutarchi Moralium, Naples.

Calvino, I. (1996), "Diario americano, 1959-1966”, in Eremita a Parigi. Pagine autobiografiche, Milano, 20-124.

Calvino, I. (1996a), Città invisibili, Milano.

Camargos, M. (2001), Villa Kyrial: crônica da Belle Époque paulistana, São Paulo.

Cameron A. (1993), The later Roman empire: AD 284-430, Cambridge.

Cantemir, D. (2006), The Salvation of the Wise Man and the Ruin of the Sinful World [...], ed., trans., notes, indices Ioana Feodorov, Editura Academiei, Bucuresti.

Cantemirius, D. (1973), Descriptio antiqui et hodierni status Moldaviae/ Dimitrie Cantemir, Descrierea Moldovei, trans. Gh. Gutu, introd. Maria Holban, hist. com. N. Stoicescu, cartographical study Vintilă Mihailescu, index Ioana Constantinescu, note D. M. Pippidi, Bucuresti. 
Bibliografia

Cantemirius, D. (2006), Descriptio antiqui et hodierni status Moldaviae/ Dimitrie Cantemir, Principele Moldovei, Descrierea stării de odinioară şi de astăzi a Moldovei, ed., trans. Dan Slusanschi, Bucuresti.

Cantineau, J. (1935), Grammaire du palmyrénien épigraphique, Le Caire.

Carcopino, J.(s/d), A vida quotidiana em Roma no apogeu do Império (trad A. J. Saraiva), Lisboa.

Cardim Ribeiro, J. (2002), "Soli Aeterno Lunae. O santuário", Religiões da Lusitânia. Loquuntur Saxa, Lisboa, 235-239.

Cardim Ribeiro, J. (2005), "O deus sanctus Endovellicus durante a romanidade. Uma interpretatio local de Faunus-Silvanus?”, Paleohispanica 5: 721-766.

Carlier p. (1990), Démosthène, Paris.

Carneiro, A., d'Encarnação, J., de Oliveira, J., Teixeira, Cl. (2008), "Uma iscrição votiva em lengua lusitana”, Palaeobispanica 8: 167-178.

Caro, A. (2009), “Una fase decisiva en la evolución de la publicidad: la transición del producto a la marca", Pensar la publicidad, III, 2: 109-114.

Caro, A. (2010), Comprender la publicidad, Barcelona.

Cartledge, P. (2009), Ancient Greek Political Thought in Practice, Cambridge.

Carvalho, J. de (1947-1948), Estudos sobre a cultura portuguesa do século XVI, 2 vols. Coimbra.

Carvalho, J. de (1949), Estudos sobre a cultura portuguesa do século XV, Coimbra.

Cascudo, L. C. (1974), Prelúdio e fuga do real, Natal.

Cascudo, L. C. (1983), Civilização e Cultura, pesquisas e notas de etnografia geral, Belo Horizonte.

Cascudo, L. C. (1983, 2ª ed.), Anúbis e outros ensaios. Mitologia e folclore, Rio de Janeiro, Natal.

Cascudo, L. C. (1987), História dos nossos gestos, Belo Horizonte, São Paulo.

Cascudo, L.C. (1966), "História de um livro perdido", Arquivos do Instituto de Antropologia "Câmara Cascudo" 2.1-2: 5-19.

Castelli, E. (1951) (ed.), Umanesimo e Scienza politica. Atti del congresso Internazionale di Studi Umanistici, Roma-Firenze, 1949, Milano.

Castillo, C. (1998), "Los flamines provinciales de la Bética", REA 100: 437-460

Cawkwell, G. (2005), The Greek Wars. The Failure of Persia, Oxford.

Cesarano, M. (2015), In honorem domus divinae. Introduzione allo studio dei cicli statuari giulio-claudii a Roma e in Occidente, Roma.

Clauss, M. (1979), Kaiser und Gott: Herrscherkult im romischen Reich, Berlin.

Chamie, M. (2009), Paulicéia dilacerada, Ribeirão Preto.

Chaniotis, A. (2009), "The Dynamics of Rituals in the Roman Empire", in O. 
Hekster, S. Schmidt-Hofner, Chr. Witschel (eds.), Ritual Dynamics and Religious Change in the Roman Empire. Proceedings of the Eight Workshop of International Network Impact of Empire, Leiden, Boston, 3-29

Charles-Picard, G., Rougé, J. (1969), Textes et documents relatifs à la vie economique et sociale dans l'Empire romain, Paris.

Chassaing, M. (1961), "Les barillets frontiniens“, RAE 12: 7-33, 89-106.

Chelotti, M. (2003), Regio II, Apulia et Calabria, Venusia (Supplementa Italica 20), Roma.

Cherry, D. (1998), Frontier and Society in Roman North Africa, Oxford.

Chevallier, R. (1972), Les voies romaines, Paris.

Chevallier, R. (1988), Voyages et déplacements dans l'Empire romain, Paris.

Chiarelli, G. (1932), 'Il 'De regno' di Francesco Patrizi', Rivista internazionale di filsosofia del diritto, Anno XII. (Nov-Dec.): 716-738.

Cistercienses (Os). Documentos primitivos. Texto latino e tradução brasileira. (1997) Introdução e bibliografia Irmão François de Place, Tradução de Irineu Guimarães, Musa, S. Paulo; Lúmen Christi, Rio de Janeiro 1997.

Clauss, J., Cuypers, M. (eds.) (2010), A Companion to Hellenistic Literature, Chichester, West Sussex.

Clavel-Lévêque, M. et alii (eds.) (1993), Siculus Flaccus. Les conditions des terres, Nápoles.

Clavel-Lévêque, M. et alii (eds.) (1996), Hygin l'arpenteur. L' établissement des limites, Nápoles.

Clayton, P.A. (1989), Le sette Meraviglie del mondo, Torino. (The Seven Wonders of the Ancient World, London, 1988).

Cogitore, I. (1996), “Séries de dédicaces italiennes à la dynastie julio-claudienne”, MEFRA 104 : 817-870.

Colasso, F. (1951), "Umanesimo giuridico", in E. Castelli (ed.), Umanesimo e Scienza politica (Atti dei Congresso Internazionale di Studi Umanistici, Roma-Firenze, 1949), Milano, 57-58.

Colecchia, A., Bertolani, G. B., Marcante, A. et alii (2004), L'Alto Garda occidentale dalla preistoria al postmedioevo. Archeologia, storia del popolamento e trasformazione del paesaggio (Documenti di archeologia, 36), Mantova.

Colonna, G. (1980), "Virgilio, Cortona e la leggenda etrusca di Dardano", Archeologia Classica 32: 1-15.

Conger, G. P. (1952), "Did India influence Early Greek Philosophies?", Philosophy East and West 2.2: 102-128.

Conti, S. (1997), "Dinastia giulio-claudia a Roselle: una serie di dediche imperiali in Etruria”, Ann. Fac. Lett. e Filos. Univ. Siena 18: 101-127. 
Conti, S. (1998), Rusellae, Suppl. It. n. s. 16, Roma.

Cook, J. M. (1971), Os Gregos na Iónia e no Oriente, Lisboa.

Cooley, A. E. (ed.) (2002), Becoming Roman, Writing Latin? Literacy and Epigraphy in the Roman West. JRA Suppl. Ser. 48, Portsmouth.

Cooley, A. E. (2002), "The survival of Oscan in Roman Pompeii”, in E. A. Cooley (ed.), Becoming Roman, Writing Latin? : Literacy and Epigraphy in the Roman West, JRA Suppl. Ser. 48: 77-86.

Cordovana, O. D., Galli, M. (eds.) (2007), Arte e memoria culturale nell'età della Seconda Sofistica, Catania.

Corell, J. (1989), “Notas sobre epigrafía romana del País Valenciano”, APL 19: 271-281.

Costa, A. D. S. (1969), Estudantes portugueses na reitoria do Colégio de S. Clemente de Bolonha na primeira metade do século XV, Lisboa.

Costa, A. D. S. (1990), Portugueses no Colégio de S. Clemente e Universidade de Bolonha durante o século $X V$, vol. I, Bolonia.

Coulanges, F. de. (1971, 10ª ed.), A cidade antiga, Trad. e glossário de Fernando de Aguiar, Livraria Clássica Editora, Lisboa.

Crawford, M. H., Reynolds, J. M. (1979), “The Aezani copy of the Prices Edict”, Zeitschrift für Papyrologie und Epigraphik 34: 163-210.

Crystal, D. (2000), Language death, Cambridge.

Curado, F. P. (1985), "Inscrição rupestre de Freixo de Numão”, Ficheiro Epigráfico 11: no48.

David, B., Thomas J. (eds.) (2008), Handbook of landscape archaeology (World archaeological congress research handbooks in archaeology, 1), Walnut Creek.

Davie, J. N. (1982), "Theseus the king in fifth-century Athens", GE'R 29.1: 2534.

DCPH = M. P. García-Bellido y C. Blázquez (2001), Diccionario de cecas y pueblos hispánicos, Madrid.

De Bernardo Stempel, P. (2008), "More names, fewer deities. Complex theonymic formulas and the three types of interpretation", in Divindades indígenas em análise. Divinités pré-romaines. Bilan et perspectives d'une recherche. Actas do VII workshop FERCAN, Cascais, 25-27.5.2006, Coimbra, 65-73.

De Hoz, J. (2001), "La lengua de los íberos y los documentos epigráficos en la comarca de Requena-Utiel”, in A. J. Lorrio (ed.), Los íberos en la comarca de Requena-Utiel (Valencia), Madrid, 49-62.

De Hoz, J. (2010), Historia lingüistica de la Península Ibérica en la Antigüedad. I. Preliminares y mundo meridional prerromano, Madrid. 
De Hoz, M. P. (1997), “Epigrafía griega en Hispania”, Epigraphica 59: 29-93.

De Labriolle, P. (1934), La reaction païenne, Paris.

De Martino, D. (2010), "Spot, etica e letteratura", La nuova ricerca. Pubblicazione annuale del Dipartimento di Linguistica, Letteratura e Filologia moderna dell'Università degli studi di Bari, anno XIX. 19, 117-128.

De Martino, D. (2010 bis), "Automobili da mito", in F. De Martino (ed.), Antichità Ẽ pubblicità, Bari, 443-522.

De Martino, D. (2011), Io sono Giulietta. Letterature E' miti nella pubblicità di auto, Bari.

De Martino, D. (2012), "Una forma de subversión del mito literario: de la novela a la publicidad", in J. M. Losada Goya, M. Guirao Ochoa (eds.), Myth and Subversion in the Contemporary Novel, Cambridge, 421-436.

De Martino, D. (2013), Dante E̋ la pubblicità, Bari.

De Martino, F., Vox, O. (1996) (eds.), Lirica greca, vol. 3, Bari.

De Ruyt, Cl. (1983), Macellum. Marché alimentaire des romains, Louvain-laNeuve.

De Santerre, H. H. (1976), "Athènes, Délos et Delphes d'après une peinture de vase à figure rouges du V siècle avant J.-C.”, BCH 100: 291-298.

De Vos, M., Andreoli, M., Attoui, R. et alii (2007), "Cilicia campestris orientale. Leconomia rurale e la trasformazione del paesaggio intorno al Karasis", in Geografia e viaggi nell'antichità. Atti del convegno internazionale di studi (Certosa di Pontognano, 9-10 ottobre 2005), Siena, 13-39.

Degl'Innocenti Pierini, R. (2012), "Le città personificate nella Roma repubblicana: fenomenologia di un motivo letterario tra retorica e poesia", in G. Moretti, A. Bonandini (eds.), Persona ficta. La personificazione allegorica nella cultura antica, fra letteratura, retorica e iconografia, Trento, 215-247.

Desbat, A. (1991), "Un bouchon de bois du Ier s. aprés J.-C. recueilli dans la Saône à Lyon et la question du tonneau à 1'époque romaine", Gallia 48: 319-336.

Dias, P. B. (2011 2a ed.), “Notas introdutórias”, in J. G Freire, A versãolatina por Pascásio de Dume dos Apophtegmata Patrum, Coimbra, 1-34.

Dias, P. B. (2012), “Cristianismo e responsabilidade cristã na queda de Roma”, in F. Oliveira et alli (coords.), A queda de Roma e o alvorecer da Europa, Coimbra, 43-67.

Dias P. B. (2013), "O legado de Constantino na identidade da Europa cristã: dois casos de estudo", in M. C. Pimentel e P. Farmhouse Alberto (orgs.), Vir bonus peritissimus aeque. Estudos de homenagem a Arnaldo do Espirito Santo, Lisboa, 455-463 
Díaz, B. (2008), Epigrafía latina republicana de Hispania, Barcelona.

Dittenberger, W., Purgold, K. (1896), Inschriften von Olympia, Berlin.

Dixon, R. M. W. (1997), The rise and fall of languages, Cambridge.

Domăneanțu, C. (1993), "Un sanctuaire hellénistique du site de Nuntaşi II (comm. d'Istria, dep. De Constanța)”, Dacia 37: 59-78.

Dörfler, W., Evans, A., Löhr, H. (1998), “Trier, Walramsneustrasse. Untersuchungen zum römerzeitlichen Landschaftswandel im Hunsrück-Eifel-Raum an einem Beispiel aus der Trierer Talweite“, in Studien zur Archäologie der Kelten, Römer und Germanen in Mittel- und Westeuropa. Alfred Haffner zum 60. Geburtstag gewidmet, Rahden, 119152.

Dubuisson, M. (1981), "Utraque lengua”, L'Antiquité Classique 50: 274-286.

Dubuisson, M. (1982), "Y a-t-il une politique linguistique romaine?”, Ktéma 7: 197-210.

Duchesne, L. (1887), "Le concile d'Elvire et les flamines chrétiens", Mélanges Renier, Paris, 159-174.

Dunkle, J. R. (1969), “The Aegeus episode and the theme of Euripides' Medea", TAPhA 100: 97-107.

Durán Fuentes, M. (2005), La construcción de puentes romanos en Hispania, Santiago de Compostela.

Eck, W. (2006), "Herrschaft und Kommunikation in antiken Gesellschaften. Das Beispiel Rom", in U. Peter, S. J. Seidlmayer (eds.), Mediengesellschaft Antike? Information und Kommunikation vom Alten Ägypten bis Byzanz, Berlin, 11-33.

Eco, U. (2013), Storia delle terre e dei luoghi leggendari, Milano.

Eddy, S.K. (1968), “Four Hundred Sixty Talents Once More”, CP 63: 184-95.

Edmonson, J. (1997), “Two dedications to Divus Augustus and Diva Augusta from Augusta Emerita and the early development of the imperial cult in Lusitania", MM 38: 89-105.

Edmondson, J. (2002), "Writing latin in the province of Lusitania", in A. E. Cooley (ed.), Becoming Roman, Writing Latin? Literary and Epigraphy in the Roman West, JRA Suppl. Ser. 48: 41-60.

Ehrenberg, V. (1973, 2a ed.), From Solon to Sócrates, Londres.

Ehrenberg, V. (1976), L'État grec, Paris.

Ehrhardt, N. (1988), Milet und seine Koloniei. Vergleichende Untersuchung der kultischen und politischen Einrichtungen, ed. a II-a, Frankfurt, Main-Bern, New York, Paris.

Elliger, W. (1975), Die Darstellung der Landschaft in der griechischen Dichtung, Berlin, New York. 
Elliott, Th. (1990), “The Language of Constantinian Propaganda”, TAPhA 120: 349-353.

Encarnação, J. d' (1984), Inscrições romanas do Conventus Pacensis, Coimbra.

Erasmo, D. (1703), Opera omnia (in decem tomos distincta), Recognovit Joannes Clericus, Leiden.

Erodoto (1988), Le Storie. Libro I. La Lidia ela Persia. Acura di David Astheri, Milano.

Erskine, A. (ed.) (2003), A Companion to the Hellenistic World, Oxford.

Espérandieu, E. (1907-1981), Recueil général des bas-reliefs, statues et bustes de la Gaule romaine, Paris.

Estarán, M. J. (2012), “Las estampillas ibérico-latinas K.5.4”, Palaeohispanica 12: $73-90$

ET = Rix, H. (1991), Etruskische Texte, Tübingen.

Étienne, R. (1958), Le culte impérial dans la Péninsule ibérique d’Auguste à Diocletien, Paris.

Étienne, R. (1973), "Les syncrétismes dans la Péninsule Ibérique à l'époque impériale", in Les syncrétismes dans les religions grecque et romaine, Paris, 153-163.

Étienne, R., Fabre, G.; Lévêque, P. et M. (1976), Fouilles de Conimbriga, vol. II, Épigraphie et Sculpture, Paris.

Étienne, R., Fabre, G., Le Roux, P., Tranoy, A. (1976), "Les dimensions sociales de la romanisation dans la Péninsule Ibérique des origines à la fin de l'Empire", in D. M. Pippidi (ed.), Assimilation et résistance à la culture gréco-romaine dans le monde ancien. Travaux du VI Congrès International d'Études Classiques, Bucureşti, Paris, 95-107.

Étienne, R., Mayet, F. (2000), Le vin hispanique, Paris.

Evans, J. A. S. (1981), "Notes on the debate of the Persian Grandees in Herodotus 3, 80-82”, QUCC 36: 79-84.

Evers, C. (1994), Les portraits d'Hadrien. Typologie et ateliers, Bruxelles.

Ewald, C., Norena, C. F. (eds.) (2010), The Emperor and Rome: Space, Representation, Ritual, Cambridge.

Fabre, G., Mayer, M., Rodà, I. (1991), Inscriptions romaines de Catalogne, III, Paris.

Fayer, C. (1976), Il culto della dea Roma. Origine e diffusione nell'Impero, Pescara.

Fearn, D. (2007), Bacchylides. Politics, performance, poetic tradition, Oxford.

Fernandes, L., Carvalho, P., Figueira, N. (2009), "Divindades indígenas numa ara inédita de Viseu", Palaeohispanica 9: 143-155.

Fernández Gallardo, L. (2002), Alonso de Cartagena. Una biografía politica en la Castilla del siglo XV, Valladolid. 
Fernández Gallardo, L. (2008), “Alonso de Cartagena y el Humanismo”, La Corónica 37.1: 175- 215.

Ferraz, C. (2002), "Conjunto de oito aras provenientes do Lararium de Centum Celas", in V. L. Raposo, J. R. Ferreira (Coords.), Religióes da Lusitânia. Loquuntur Saxa, Lisboa, 467-469.

Ferreira, J. R. (1988), "Grécia e Roma na Revolução Francesa”, Revista de História das Ideias 10: 203-234.

Ferreira, J. R. (1990), A democracia na Grécia Antiga, Coimbra.

Ferreira, J. R. (1990a), Participação e poder na democracia grega, Coimbra.

Ferreira, J. R. (1993), Hélade e Helenos I - Génese e Evolução de um Conceito, Coimbra.

Ferreira, J. R. (2004 2a ed.), A Grécia Antiga. Sociedade e Politica, Lisboa.

Ferreira, J. R., (1991), "Presença da Grécia e de Roma na Revolução Francesa", in Actas do colóquio A Recepção da Revolução Francesa em Portugal e no Brasil, Porto, vol. I, 75-96.

Ferri, S. (1976), "Luci e ombre sulla interpretatio romana", in Convegno internazionale "Renania romana" Roma 14-16 aprile 1975, Roma, 125133.

Ferrill, A. (1978), "Herodotus on tyranny", Historia 27.3: 385-398.

Figueira, T. J. (1998), The Power of Money: Coinage and Politics in the Athenian Empire, Philadelphia.

Figueira, T. J. (2003), "Economic Integration and Monetary Consolidation in the Athenian Arkhê", in G. Urso (ed.), Moneta, Mercanti, Banchieri. I precedenti greci e romani dell'Euro, Pisa, 71-92.

Figueira, T. J. (2005), "The Imperial Commercial Tax and the Finances of the Athenian Hegemony”, Incidenza dell'antico 3: 83-133.

Figueira, T. J. (2006), "Reconsidering the Athenian Coinage Decree", AIIN 52: 9-44.

Figueira, T. J. (2011), "The Athenian Naukraroi and Archaic Naval Warfare”, Cadmo. Revista de História Antiga 21: 183-210.

Figueira, T. J. (forthcoming[a]), "Archaic Naval Warfare”, in N. Birgalias (ed.), Great is the Power of the Sea: The Power of Sea and Sea Powers in the Greek world of the Archaic and Classical Periods, Athens.

Figueira, T. J. (forthcoming[b]), "The Aristeidian Tribute on the Peace of Nikias", in S. Jensen, T. Figueira (eds.), Athenian Hegemonic Finances, Swansea.

Figueira, T. J. (forthcoming[c]), "Community Wealth and Military Might in Periclean Athens", in A.L. Pierris (ed.), Mind, Might, Money: The Secular Triad in Classical Athens, Patras. 
Figueira, T. J. (forthcoming[d]), “Aigina: Island as Paradigm”, in A. Powell and K. Meidani (eds.), The Eyesore of Aigina: Anti-Athenian Attitudes in Greek, Hellenistic and Roman History, Swansea.

Figueiredo, R., Lamounier, B. (1996), As cidades que dão certo, Brasília.

Finley, M.I. (1966), The Ancient Greeks. An introduction to their life and thought, Londres. Trad. port.: Os Gregos Antigos (Lisboa, 2a ed. 1988).

Finley, M. I. (1973, 2a ed.), Democracy, ancient and modern, London.

Finley, M.I. (1973a), The ancient economy, London.

Finley, M.I. (1982), Authority and legitimacy in the classical city-state, Kobenhavn.

Fishwick, D. (1970), "Flamen Augustorum”, HSCPh 74: 299-312.

Fishwick, D. (1982), "The altar of Augustus and the municipal cult of Tarraco", MM 23: 222-233

Fishwick, D. (2002), The Imperial Cult in the Latin West, 3/2, Provincial Cult I The Provincial Priesthood, Leiden.

Fishwick, D. (2005), The Imperial Cult in the Latin West. Studies in the Ruler Cult of the Western Provinces of the Roman Empire, Leiden, Boston.

Fitton, J. W. (1961), "The Suppliant Women and the Herakleidai of Euripides", Hermes 89.4: 430-461.

Flower, M. F. (2007), "Appendix R: The Size of Xerxes Expeditionary Force," in Robert B. Strassler (ed.), The Landmark Herodotus: The Histories, New York, 819-23.

Fonseca, L. A. (1982), O Condestável D. Pedro de Portugal, Porto.

Fontanella, F. (2008), "The Encomium on Rome as a response to Polybius' doubts about the Roman Empire", Columbia Studies in the Classical Tradition 33: 203-216.

Forni, G. (1973), "El culto de Augusto en el compromiso oficial y en el sentimiento oriental", BSAA 39: 105-113.

Forni, G. (1994), Scritti vari di Storia, Epigraphia e antichità romane, Roma.

Franck, A. D. (1864), Réformateurs et publicistes de l'Europe: Moyen ÂgeRenaissance, Paris.

French, A. (1972), "The Tribute of the Allies", Historia 21: 3-20.

Fuentes, M. J. (1986), Corpus de las inscripciones fenicias, púnicas y neopúnicas de Hispania, Barcelona.

Gabba, S., Drioton, É. (1954), Peintures à fresques et scènes peintes a Ermoupolis Ouvest (Touna el-Gevel), Le Caire.

Gaffiot, F. (s/d), Dictionnaire latin-français, Paris.

Gagé, J. (1936), "Le templum Urbis et les origines de l'idée de Renovatio", in Mélanges Franz Cumont, Bruxelles, 151-187. 
Gagé, J. (1955), Apollon romain. Éssai sur le culte d'Apollon et le développement du "ritus Graecus" à Rome des originrs à Auguste, Paris.

Gagé, J. (1968), "Basiléia”. Les Césars, les rois d'Orient et les "mages", Paris.

Gagé, J. (1974), "Le solemne Urbis du 21 avril au III" siècle ap. J.-C.: Rites positives et speculations séculaires", Mélanges d'histoire de religions offerts à Henri-Charles Puech, Paris, 225-241.

García Bellido, M. P. (1993), "Sobre el culto de Volcanus y Sucellus en Hispania. Testimonios numismáticos", in F. Burkhater, J. Arce (eds.), Bronces y religión romana. Actas del XI Congreso internacional de bronces antiguos, Madrid mayo - junio 1990, Madrid, 161-170.

García Iglésias, L. (1976), "Autenticidad de la inscripción de municipios que sufragaron el puente de Alcántara”, Revista de Estudios Extremeños 32.2: 263-276.

García Jurado, F. (2007), Aulo Gelio, Noches Aticas. Antología, Madrid.

García Romero, F. (2002), "Pervivencia de Penélope”, in C. Morenilla Talens, F. De Martino (eds.), El perfil de les ombres, Bari, 187-204.

García Soler, M. J. (2010), "Gastronomia e pubblicità nella Grecia antica”, in F. De Martino (ed.), Antichità Ẻ pubblicità, Bari, 345-366.

Garin, E. (1955), "Ricerche sulle traduzioni di Platone nella prima metà del XV secolo", Medioevo e Rinascimento, Studi in onore di B. Nardi, Firenze.

Garin, E. (1966), Storia della filosofia italiana, Torino.

Garriguet, J. A. (2004), "Grupos estatuarios imperiales de la Bética: la evidencia escultórica y epigráfica”, in Actas de la IV reunión sobre escultura romana en Hispania, Madrid, 67-101.

Gasperini, L. (1977), “L’Augusteo di Firmo Piceno in un'epigrafe da rileggere”, AFML 10: 57-87.

Gasperini, L. (2008), "L’Augusteo di Forum Clodii”, en L. Gasperini, G. Paci, (eds.), Nuove ricerche sul culto imperiale in Italia, Tivoli, 91-134.

Gasperini, L., Paci, G. (eds.) (2008), Nuove ricerche sul culto imperiale in Italia, Tivoli.

Gaudemet J. (1947), “La législation religieuse de Constantin”, Rérue d' Histoire de l'Église de France 122: 25-61.

Genette, G. (1997), Palinsesti. La letteratura di secondo grado, Torino.

Gentili, B. (ed.) (1995), Pindaro. Le pitiche, Milano.

Ghedini, F. (2000), "Filostrato Maggiore come fonte per la conoscenza della pittura antica”, Ostraka 9.1: 75-197.

Giachero, M. (ed.) (1974), Edictum Diocletiani et Collegarum de pretiis rerum venalium in integrum restitutum e latinis gracisque fragmentis, 1-2, Génova. 
Gico, V. (1998), "Luís da Câmara Cascudo: perfil bibliográfico", in L. C. Cascudo, Ontem. (Maginaçôes e notas de um professor de provincia), Natal.

Gigli, D. (1985), Metafora e poetica in Nonno di Panopoli, Firenze.

Gilles, K. J. (1987), "Römische Glasgefäße", in AA.VV., 2000 Jahre Weinkultur an Mosel-Saar-Ruwer. Denkmäler und Zeugnisse zur Geschichte von Weinbau, Weinhandel, Weingenuß, Trier, 143-145.

Gilles, K. J. (1987b), “Trierer Weinkeramik”, in AA.VV., 2000 Jabre Weinkultur an Mosel-Saar-Ruwer. Denkmäler und Zeugnisse zur Geschichte von Weinbau, Weinhandel, Weingenuß, Trier, 132-133.

Gilles, K. J., König, M., Schumann, F. (1995), Neuere Forschungen zum römischen Weinbau an Mosel und Rhein (Schriftenreihe des Rheinischen Landesmuseums Trier, 11), Trier.

Gilson, É. (1983, 6ª ed.), Le thomisme, Paris.

Gómara, M. (2007), "Una inscripción paleohispánica sobre cerámica altoimperial en Cascante (Navarra)", Palaeohispanica 7: 263-268.

Gomes, S.A. (1998), Visitações a mosteiros cistercienses em Portugal. Séculos XVe XVI, Ministério da Cultura - IPPAR, Lisboa.

Gomes, S. A. (2000), "Revisitação a um velho tema: a fundação do Mosteiro de Alcobaça”, in Cister: Espaços Território e Paisagens. Colóquio Internacional, 16-20 Junho de 1998, Mosteiro de Alcobaça. Actas. I, Lisboa, 27-72.

Gomes, S. A. (2000), O mosteiro de Alcobaça na transição dos séculos XIV e XV: o protagonismo de D. João Dornelas, in Cister. Espaços, Territórios, Paisagens. Colóquio Internacional. 16-20 Junho 1998. Mosteiro de Alcobaça, Lisboa, 73-88.

Gomes, S. A. (2006), D. Afonso V, Círculo de Leitores-Colecção Reis de Portugal, Lisboa.

Gómez García, C. (2010), "La configuración de la ciudad de Berlin”, in J. M. Losada Goya (ed.), Mito y mundo contemporáneo. La recepción de los mitos antiguos, medievales y modernos en la literatura contemporánea, Bari , 617626.

González Rolán, T., P. Saquero Suárez-Somonte, P. (2001), “E1 Humanismo italiano en la Castilla del cuatrocientos: estudio y edición de la versión castellana y del original latino del De infelicitate principum de Poggio Bracciolini “, Cuadernos de Filología Clásica. Estudios Latinos 21: 115-150.

González Rolán, T., Moreno Hernández, A., Saquero Suárez-Somonte, P. (2000), Humanismo y teoría de la traducción en España e Italia en la primera mitad del siglo XV. Edición y estudio de la Controversia Alphonsiana (Alfonso de Cartagena vs. L. Bruni y P. Candido Decembrio), Madrid.

Gorrochategui, J. (1987), "Situación lingüística de Navarra y aledaños en la antigüedad a partir de las fuentes epigráficas", Primer Congreso General de Historia de Navarra II, Pamplona, 435-445. 
Gorrochategui, J. (2014), "Nueva inscripción funeraria celtibérica procedente de Clunia”, Palaeobispanica 14: 229-236.

Gorrochategui, J.y Vallejo, J. M. (2010), “Lengua y onomástica. Las inscripciones lusitanas", Iberografías 6: 71-80.

Gose, E. (1976), Gefäßtypen der römischen Keramik im Rheinland, Köln.

Graham, A.J. (1964), Colony and Mother City, Manchester.

Grenier, A. (1934), Manuel d'archéologie gallo-romaine 2, Les routes, Paris.

Gros, P., Marin, M., Zink, M. (eds.) (2015), Auguste, son époque et l'Augusteum de Narona. Actes du colloque organisé à l 'Académie des Inscriptions et Belles-letres le 12 décembre 2014, Paris.

Gualandi, M. L. (2001), Le fonti per la storia dell'arte - I. L'antichità classica, Roma.

Guarducci, M. (1974), Epigrafia greca, vol. III, Roma.

Guarducci, M. (1978), Epigrafia greca, vol. IV, Roma.

Guerra, A., Schatner, T. (2010), "El foro y el templo de Lancia Oppidana: nueva interpretación de Centum Celas (Belmonte)", in T. Mogale Basarrate (ed.) Ciudad y Foro en Lusitania Romana, Mérida, 333-342.

Guilaine, J. (cur.) (1991), Pour une archéologie agraire: à la croisée des sciencies de l'homme et de la nature, Paris.

Guilmartin, J. F. (2002), Galleons and Galleys, London.

Guilmartin, J. F. (2003), Gunpowder and Galleys. Changing Technology and Mediterranean Warfare at Sea in the Sixteenth Century, 2nd ed., Annapolis.

Hall, J. M. (1997), Ethnic identity in Greek Antiquity, Cambridge.

Hanell, K. (1934), Megarische Studien, Lund.

Hänlein-Schäfer, H. (1985), Veneratio Augusti. Eine Studie zu den Tempeln der ersten römischen Kaisers, München.

Hanley, R. (2000), Villages in Roman Britain, Princes Risborough.

Hansen, H. M. (1991), The Athenian Democracy in the age of Demosthenes. Structure, Principles and Ideology, Oxford.

Hardy, E. G. (1925), "The Lex Mamilia Roscia Peducaea Alliena Fabia”, The CQ 19 (3/4): 185-191.

Harris, E. (1995), Aeschines and Athenian Politics, Oxford.

Harth, H. (1984), Poggio Bracciolini, Lettere, Leo S. Olschki Editore, Florencia.

Hekster, O., Schmidt-Hofner, S., Witschel, Chr. (eds.) (2009), Ritual dynamics and Religious Change in the Roman Empire. Proceedings of the Eighth Workshop of the International Network Impact of Empire, Leiden, Boston.

Helck, W. (1971), Das Bier im alten Ägypten, Berlin. 
Hershowitz, A., (forthcoming), "Patterns in Variation in Tribute Assessment", in S. Jensen, T. Figueira (eds.), Athenian Hegemonic Finances, Classical Press of Wales, Swansea.

Herta, P. (1978), "Bibliographie zum römischer Kaiserkult (1955-1975)", ANRW II 18: 833-910.

Heubeck, A. (ed.) (1983), Omero. Odissea, Volume III (Libri IX-XII), Milano.

Heurgon, J. (1950-1951), "La syntaxe des routiers romains", Bulletin de la Société des Antiquaires de France: 145-154.

Heurgon, M. (1969), "Inscriptions étrusques de Tunisie”, CRAI, 526-551.

Heurgon, M. (1969a), “Les Dardaniens en Afrique”, REL 47: 284-294.

Higbie, C. (2007), "Hellenistic Mythographers", in R. Woodart (ed.), The Cambridge Companion to Greek Mythology, Cambridge, 237-54.

Hignett, C. (1963), Xerxes' Invasion of Greece, Oxford.

Hoffmann, C. (1991), An introduction to bilingualism, London, New York.

Hoffmann, M. (1956), 5000 Jahre Bier, Berlin.

Holban, M., Bulgaru, M. M. A., Cernovodeanu, P. (eds.) (1980-83), Calatori straini despre tarile române (Foreign Travellers about the Romanian Countries), Bucuresti, vol. VII: 1980; vol. VIII: 1983.

Homo, L. (1972), Rome impériale et l'urbanisme dans l'antiquité, Paris.

Hopkinson, N. (1984), “Callimachus' Hymn to Zeus”, CQ 34: 139-148.

Hornblower, S. (2008), A Commentary on Thucydides. Volume I: Books I-III, Oxford - New York.

Houaiss, A. (2001), Dicionário Houaiss da lingua portuguesa, Rio de Janeiro.

Howgego, Chr, Heuchert, V. Burnett, A. (eds.) (2004), Coinage and identity in the Roman provinces, Oxford.

Howgego, Chr. (2004), "Coinage and identity in the Roman provinces", in Chr. Howgego, A. Heuchert y Burnett (eds.), Coinage and identity in the Roman provinces, Oxford, 1-18.

Huizinga, J. (1948), Le déclin du Moyen Âge, Paris.

Hunter, R., Fuhrer, T. (2002), "Imaginary Gods? Poetic Theology in the Hymns of Callimachus", in F. Montanari, L. Lehnus (eds.), Callimaque. Sept Exposés suivis de discussions, Vandoeuvros-Gender, 143-175.

Hurlet, F. (1996), Les collègues du prince au temps d'Auguste et de Tibére: de la légalité républicaine à la légitimité dynastique, Roma.

Hutchinson, G. O. (1988), Hellenistic Poetry, Oxford.

HCT = Gomme, A. J., (1970), A Historical Commentary on Thucydides. vs. 1-2, Oxford. 
Icks, M. (2001), "Priestohood and Imperial Power. The Religious Reforms of Heliogabalus 220-222", in L. de Blois (ed.), Administration, Prosopography and Appointment Policies in the Roman Empire. Proceedings of the First Workshop of the International Network Impact of Empire (Roman Empire, 27 B.C. - A.D. 406), Amsterdam, 169-178.

$I R T=$ Reynolds , J. M., Ward-Perkins, J. B. (1952), Inscriptions of Roman Tripolitania, Rome.

Jackson. K. (1953), Language and history in Early Britain, Edinburgh.

Jacoby, F. (1923), Die Fragmente der griechischen Historiker, Part I-III, Berlin.

Jaeger, W. (s.d), Paideia, Trad. de Artur M. Parreira, São Paulo.

Janko R. (1982), Homer, Hesiod and the Hymns, Cambridge.

Jiménez, A. J. (1995), "La imagen de Teseo en las Suplicantes", in J. A. López Férez (ed.), De Homero a Libanio, Madrid, 145-161.

Johnson, L. (1960), "Natalis urbis and principium anni", TPAPhA 91: 109-120

Julia, D. (1962), "Les monuments funéraires en forme de demi-cylindre dans la province romaine de Tarragonaise", MCVI : 29-54.

Jullian, C. (1926), "Notes gallo-romaines”, Rérue des Études Anciennes 28. 2: 139-151.

Little, K. (2002), "Monasticism and Western Society: from marginality to the establishment and back", Memoirs of the American Academy in Rome 47: 83-94.

Kaimio, J. (1979), The Romans and the Greek Language, Helsinki.

Kalinowski, A. (2007), "A series of honorific statue bases for the Vedii in the market agora at Ephesos (IvE 725, 731, 3076-3078)", in M. Mayer, G. Baratta, A. Guzmán, (eds.), Acta XII Congressus internationalis epigraphiae Graecae et Latinae. Provinciae imperii Romani inscriptionibus descriptae, vol I, Barcelona, 757-762.

Kantiréa, M. (2007), Les dieux et les dieux augustes. Le culte impérial en Grèce sous le Julio-claudiens et les Flaviens, Études épigraphiques et archéologiques, Athènes.

Katz, S. H., Fleming, S. J., McGovern, P. E. (1996), The origins and ancient history of wine. Food and nutrition in history and anthropology 11, Amsterdam.

Kelso W.M. (ed.) (1990), Earth patterns. Essays in landscape archaeology, Charlottesville.

Kerkhecker, A. (1999), Callimachus' Book of "Iambi", Oxford.

Khanoussi, M. (1983), “Nouvelles sépultures d'époque romaine”, in Beschaouch A. et alii (eds.), Recherches archéologiques franco-tunisiennes à Bulla-Regia, I (CEFR 28/I), Roma, 93-106.

Kiss, Z. (1975), L'iconographie des princes julio-claudiens au temps d'Auguste et de Tibère, Varsovie. 
Kleiner, F. S. (1991), "The trophy on the bridge and the Roman triumph over nature", L'Antiquité Classique 60: 182-192.

Koch, J. (2009), Tartessian. Celtic in the South-west at the dawn of history, Aberystwyth.

Koch, J. (2009a), "A case for Tartessian as a Celtic language", Palaeohispanica 9: 339-351.

Kolb, A. (2001), "Tansport and communication in Roman state: the cursus publicus", in C. Adams and R. Laurence (eds.), Travel and Geography in the Roman Empire, Londres - Nova Iorque, 95-105.

Kolb, A. (ed.) (2010), Augustae. Machtbewusste Frauen am römischen Kaiserhof? Herrschaftsstrukturen und Herrschaftspraxis, Berlin.

Kozakai, T. (2000), L'étranger, l'identité. Essai sur l'integration culturelle, Paris.

Kramer, N., Reitz, Chr. (eds.) (2010), Tradition und Erneuerung. Mediale Strategien in der Zeit der Flavier, Berlin, New York.

Kristeller, P. O. (1961, 3a ed.), “The moral thought of Renaissance humanism”, in Chapters in Western civilization, I, New York, 289-335.

Krynen, J. (1981), Idéal du prince et pouvoir royal en France à la fin du Moyen Âge (1380-1440). Étude de la littérature politique du temps, Paris.

Kuhoff, W. (2001), Diokletian und die Epoche der Tetrarchie, Frankfurt.

Künzl, S. (1997), Die Trierer Spruchbecherkeramik. Dekorierte Schwarzfirniskeramik des 3. und 4. Jahrbunderts (Beihefte Trierer Zeitschrift 21), Trier.

Lambert, P. Y. (1994), La langue gauloise, Clamecy.

Lambrino, S. (1937), "La famille d'Apollon à Histria”, Aephem 100: 352-362.

Lambrino, S. (1952), "Les inscriptions de São Miguel de Odrinhas”, Bulletin des Études Portugaises 16: 134-176.

Lasserre, F. (1976), "Hérodote et Protagoras: le débat sur les constitutions", $M H$ 33: 65-84.

Lateiner, D. (1984), "Herodotean historiographical patterning: the constitutional debate", QS 20: 257-284.

Laurence, R. (2001), "Afterword: travel and empire", in C. Adams and R. Laurence (eds.), Travel and Geography in the Roman Empire, Londres / Nova Iorque, 167-176.

Lausberg, H. (1990, 3a ed.), Handbuch der literarischen Rhetorik. Eine Grundlegung der Literaturwissenschaft, Stuttgart.

Lawrance, J. N. H. (1990), "Humanism in the Iberian Peninsula", in A. Goodman, A. Mackay (eds.), The Impact of Humanism on Western Europe, Londres, 220-258.

Lazenby, J. F. (1993), The Defence of Greece, 490-479 B.C., Warminster. 
Leão, D. F. (2012), A Globalização no Mundo Antigo. Do Polites ao Kosmopolites, Coimbra.

Lehmann, K. (1962), "Ignorance and search in the villa of the Mysteries", JRS 52: $62-68$.

Leite de Vasconcelos, J. (1913), Religióes de Lusitania, III, Lisboa 1989.

Leite, S. (ed.) (1963), Estatutos da Universidade de Coimbra (1559), Coimbra.

Lekai, L. J. (1987), Los Cistercienses. Ideales y realidad, Barcelona.

Lemny, S. (2010), Cantemirestii. Aventura europeana a unei familii princiare din secolul al XVIII-lea (Les Cantemir: l'aventure européenne d'une famille princière au XVIIIe siècle, 2006), Iasi, Polirom.

Lesky, A. (1995), História da Literatura Grega, Lisboa.

Leveau, Ph. (1992), "Le territoire agricole d'Arles dans l'antiquité. Relecture de l'histoire économique d'une cité antique à la lumiere d'une histoire du milieu”, in M. Bernardi (cur.), Archeologia del Paesaggio, Firenze, vol. II, 597-636.

Levy, A. M. (2010), Sex Acts in Early Modern Italy: Practice, Performance, Perversion, Punishment, Farnham.

Lewis, D. M, Boardman, J., Hornblower, S., Ostwald, M (eds.) (1994), The Cambridge Ancient History, Volume 6: The Fourth Century BC, Cambridge.

Lewis, D. M. (1994), “The Athenian Tribute Quota Lists, 453-450 BC”, BSA 89: 285-301.

Lima, D. C. (1998, 3a ed.), Câmara Cascudo: um brasileiro feliz. Rio de Janeiro.

Lintott, A. (1992), Judicial reform and land reform in the Roman Republic, Cambridge.

Little K. (2002), "Monasticism and Western Society: from marginality to the establishment and back", Memoirs of the American Academy in Rome 47: 83-94.

Littman, R. J. (1974), The Greek experiment, Imperialism and social conflict 800400 B. C., Londres.

Liverani, P. (1994), "Il ciclo di ritratti del edificio absidato a Roselle", in Roselle: iconografia imperiale e glorificazione Familiare, MDAI, RA 101: 161-163.

Loeschcke, S. (1932), "Römische Denkmäler vom Weinbau an Mosel, Saar und Ruwer", TrZ 7: 42-60.

Loeschcke, S. (1933), Denkmäler vom Weinbau aus der Zeit der Römerherrschaft an Mosel, Saar und Ruwer, Trier.

López Moreda, S. (2009), Aulo Gelio, Noches Aticas, Madrid.

López Vilar, J. (1999-2000), “Consideracions sobre les cupae i altres estructures funeràries afins”, Bullettí Arcqueològic V. 21-22: 65-103. 
Lorenzo Gómez, F. (2010), Un dios entre los hombres. La adoración a los emperadores romanos en Grecia, Barcelona.

Losada Goya, J. M. (ed.) (2010), Mito y Mundo contemporáneo. La recepción de los mitos antiguos, medievales y modernos en la litetatura contemporânea, Bari.

Lucet, B. (1977), Les codifications cisterciennes de 1237 et de 1257, Paris.

Macan, R.W. (1908), Herodotus, The Seventh, Eighth, E Ninth Books, London.

Machado de Assis, J. M. (1971), "Esaú e Jacó", in Machado de Assis, Obra Completa, Rio de Janeiro, José Aguilar Editora.

Maehler, H. (1982), Die Lieder des Bakchylides I (2 vols.), Leiden.

Magioncalda, A. (1991), Lo sviluppo della titolatura imperiale da Augusto a Giustiniano attraverso le testimonianze epigrafiche, Torino.

Magueijo, C. (1970), “A Lex Metallis Dicta”, O Arqueólogo Português série 3, 4: 125-163.

Maltese, V. E.-Cortassa, G. (eds.)(2000), Roma parte del cielo. Confronto tra l'Antica e la Nuova Roma di Manuele Crisolora, Torino.

Mamede, Z. (1970), Luis da Câmara Cascudo: 50 anos de vida intelectual 1918/1968, Natal.

Manconi, D., Catalli, F. (eds.) (2005), Le immagini del potere. Il potere delle immagini. L'uso del ritratto ufficiale nel mondo romano da Cesare ai Severi, Perugia.

Mann, C. (2001), Athlet und Polis im archaischen und frübklassischen Griechenland, Göttingen.

Mantas, V. G. (2008-2009), "A rede viária romana em Portugal. Estado da questão e perspectivas futuras", Anas 21-22: 245-272.

Mantas, V. G. (2011), "Linhas fortificadas e vida quotidiana: da Muralha da China à Muralha do Atlântico", in C. Guardado da Silva (coord.), A Vida quotidiana nas Linhas de Torres Vedras, Torres Vedras, 15-56.

Mantas, V. G. (2012), As vias romanas da Lusitânia, Mérida.

Maquiavel, N. (2010, 8ª ed), O principe, Trad. de Pietro Nassetti, Martin Claret, São Paulo.

Maquiavel, N. (1980), Le Prince de Maquiavel, Traduction et commentaire de C. Roux-Lehman, Paris.

Maravall, J. A. (1972), Estado moderno y mentalidad social (siglos XV a XVII), 2 vols., Madrid.

Marco, F. (1993), "Nemedus Augustus", in I. J. Adiego, J. Siles, J. Velaza, (eds.), Studia Palaeohispanica et Indogermanica J. Untermann ab amicis Hispanicis oblata, Barcelona, 163-178. 
Marco, F. (1996), "Integración, interpretatio y resistencia religiosa en el occidente del imperio", in J. M. Blásquez, J. Alvard (ed.) La romanización en Occidente, Madrid, 217-238.

Marcos Casquero, M. A., Domínguez García, A. (2006), Aulo Gelio, Noches Áticas, vol. I, Universidad de León.

Marcy, G. (1936), Les inscriptions libyques bilingues de l'Afrique du nord, Paris.

Moreno Gallo, I. (2006),Vias romanas: ingenieria y técnica constructiva. Madrid.

Marlière, É. (2001), Le tonneau en Gaule Romaine», Gallia 58: 181-201.

Marlière, É. (2002), L'outre et le tonneau dans l'Occident romain, Montagnac.

Marques, M. A. F. (1998), "A introdução da Ordem de Cister em Portugal”, in Estudos sobre a Ordem de Cister em Portugal, Lisboa.

Marrou, H.-I. (1963), "L'Église dans la première moitié du quatrième siècle”, in L'Église de l'Antiquité tardive 303-604, Paris, 26-35.

Marrou, H.-I. (1965, 6ª ed.), Histoire de l'éducation dans l' Antiquité, Paris.

Marshall, P. K (1983), "Aulus Gellius", in L.D. Reynolds (ed.), Texts and Transmission. A Survey of the Latin Classics, Oxford.

Martínez, A. (1993), "Dos esgrafiados ibéricos sobre una estela romana de Requena (Valencia)", Saguntum 26: 247-251.

Martínez-Pinna, J. (2002), "Los arcadios", in La prebistoria mitica de Roma, Gerión. Anejos 6: 135-167.

Martini, W. (1990), Die archäischen Plastik der Griechen, Darmstadt.

Mastino, A. (1981), Le titolature di Caracalla e Geta attraverso le iscrizioni (indici), Bolonia.

Mattoso, A., (1935 2a ed.), Compêndio de história antiga, Sá da Costa, Lisboa.

Maurice, F. (1930), "The Size of the Army of Xerxes in the Invasion of Greece 480 B.C.", JHS 50: 210-35.

Mayer, M. (1980), "La plasmación lingüística de la pervivencia de los cultos prerromanos en Hispania a través de los formularios epigráficos", Revista Española de Lingüistica 10: 230-231.

Mayer, M. (1993), "El paganismo cívico de los siglos II y III en la Hispania citerior. Su reflejo en la epigrafía", in Ciudad y comunidad civica en Hispania. Siglos II y III d. C. Cité et communauté civique en Hispania, Madrid, 161-175.

Mayer, M. (1995), "El primer horizonte epigráfico en el litoral noreste de la Hispania citerior", in F. Beltrán (ed.), Roma y el nacimiento de la cultura epigráfica en Occidente, Zaragoza, 97-119.

Mayer, M. (1998), “¿Qué es un Augusteum?, Historia Antiqua 4: 63-70.

Mayer, M. (1999), “Aproximación a la religión cívica en Hispania bajo los 
flavios", Ktema 24: 341-345.

Mayer, M. (2004), "El Augusteum de Narona (Vid, Metković, Croacia) en época de los Severos", in Orbis Antiquus. Studia in honorem Ioannis Pisonis, ClujNapoca, 283-289.

Mayer, M. (2005), "Constantino el Grande: deconstrucción y construcción de un Imperio", in F. de Oliveira (coord.), Génese e Consolidação da Ideia de Europa, vol. III, O Mundo Romano, Coimbra, 203-230.

Mayer, M. (2007a), "La presenza imperiale nelle città del Picenum tra l'epoca augustea e il regno dei Severi : un primo aproccio", Studi Maceratesi 41: 27-40.

Mayer, M. (2007b), "Las dedicatorias a miembros de la domus Augusta julio-claudia y su soporte: una primera aproximación”, in G. Paci (ed.), Contributi all'epigrafia del'età augustea. Actes de la XIII' Rencontre francoitalienne sur l'épigraphie du monde romain, Tivoli, 171-199

Mayer, M. (2008), "Sila y el uso político de la epigrafía", in M. Caldelli, G. L. Gregori, S. Orlandi (eds.), Epigrafia 2006. Atti della XIVerencontre sur l'épigraphie in onore di Silvio Panciera con altri contributi di colleghi, allievi e collaboratori, Roma, 121-135.

Mayer, M. (2009), "Los honores recibidos por la familia de Marco Aurelio en la parte oriental del imperio romano: ¿̨cambio o continuidad en el culto dinástico?", in A. Martínez Fernández (ed.), Estudios de Epigrafía Griega, La Laguna, 277-294.

Mayer, M. (2010), "La presència de la dinastia antonina a Tarraco", in Studia Celtica Classica et Romana Nicolae Szabó septuagesimo dicata, Budapest, 159-167.

Mayer, M. (2015), "La epigrafia y el Augusteum de Narona", in G. Zecchini (ed.), L 'Augusteum di Narona. Atti della Giornata di Studi. Roma 31 maggio 2013, (Centro ricerche e documentazione sull' antichità clàssica, monografie, 3 7), Roma, pp. 19-41.

McCrum, M., Woodhead, A.G. (1961), Select Documents of the Principates of the Flavian Emperors Including the Year of Revolution, A.D. 68-96, Cambridge.

Mednikarova, I. (2003), "The accusative of the name of the deceased in Latin and Greek epitaphs", ZPE 143: 117-134.

Meiggs, R. (1972), The Athenian Empire, Oxford.

Melani, V., Vergari, M. (1985), Profilo di una città etrusca Roselle, Pistoia.

Melchor Gil, E. (1992), "Sistemas de financiación y medios de construcción de la red viaria hispana”, Habis, 23: 121-137.

Melchor Gil, E. (2010), "Homenajes estatutarios e integración de la mujer en la vida pública municipal de las ciudades de la Bética", in F. J. Navarro (ed.), Pluralidad e integración en el Mundo Romano, Pamplona, 221-245. 
Mellor, R. (1975), ӨEA P $\Omega$ MH the Worship of the Goddess Roma in the Greek World, Göttingen.

Mellor, R. (1981), “The Goddess Roma”, in $A N R W$ II 17. 2, Berlin, New York, 950-1030

Menegazzi, L. (1995), Il manifesto italiano (prima ed. 1974), Milano.

Merêa, P. (1929), História de Portugal, Vol. II. Coimbra.

Merêa, P. (1941), Suárez, Grácio, Hobbes, Coimbra.

Mesnard, P. (1977), Essor de la philosophie politique au XVIe Siècle, Paris.

Messerschmidt, W. (2003), Prosopopoiia: Personifikationen politischen Charakters in spätklassischer und hellenistischer Kunst, Köln.

Michelini, A. N. (1994), "Political themes in Euripides' Suppliants", AJPh 115. 2: $219-252$.

Millar, F. (1968), "Local cultures in the Roman Empire: Libyan, Punic and Latin”, JRS 58: 126-134.

Millar, F. (1993), The Roman Near East 31 BC-337 AD, London.

Millar, F. (2006), A Greek Roman Empire, Power and belief under Theodosius II 408-450, Berkeley.

Minerath, R. (1996), Histoire des Conciles, Paris.

$M L H=$ J. Untermann, J. (1975-2000), Monumenta linguarum Hispanicarum, $\mathrm{I}-\mathrm{V}$, Wiesbaden.

Moggi, M. (1976), I sinecismi interstatali greci, Pisa.

Moncada, C. (1947), Filosofia do direito e do estado, I, Coimbra.

Monfrin, J. (1964), "Humanisme et traductions au Moyen Age", in L'Humanisme médieval dans les littératures romanes du XIIe au XIVe siècle (Actes du Colloque organisé par le Centre de Philologie et de Littératures romanes de l'Université de Strasbourg), Paris.

Monteiro, N., d'Encarnação, J. (1993-1994), “A propósito de uma inscrição latina em Santiago da Guarda (Ansião)", Conimbriga 32-33: 303-311.

Moretti, G. (2007), "Patriae trepidantis imago. La personificazione di Roma nella Pharsalia fra ostentum e disseminazione allegorica", Camenae 2: 1-17

Morrison, A. D. (2007), The Narrator in Archaic Greek and Hellenistic Poetry, Cambridge.

Mosley, D. J. (1965), "The Size of Embassies in Ancient Greek Diplomacy”, ТРАРЬA: 255-266.

Mosley, D. J. (1972), "Envoys and diplomacy in Ancient Greece”, Historia 22: 1-97.

Mossé, Cl. (1970), La colonisation dans l'Antiquité, Paris, 27-99. 
Mullen, A. (2007), “Linguistic evidence for 'romanization': continuity and change in Romano-British onomastics: a study of the epigraphic record with particular reference to Bath", Britannia 38: 35-61.

Muñoz, V. (2005), "La interpretatio romana del dios prerromano Bandue", Veleia 22: $145-152$.

Munro, J.A.R. (1926), “Xerxes' Invasion of Greece”, in The Persian Empire and the West, Cambridge Ancient History, Vol. IV, Cambridge, 268-316.

Nascimento, A. A. (1990), "Poggio e o seu interesse por códices de Alcobaça", Revista da Faculdade de Letras de Lisboa 13-14: 37-40.

Nascimento, A. A. (1993), "As librarias dos príncipes de Avis", Biblos. Revista da Faculdade de Letras (Coimbra). Actas do Congreso Comemorativo do $6^{\circ}$ Centenário do Infante D. Pedro (25 a 27 de Novembro de 1992) 69: 265-287.

Nascimento, A. A. (1995), "La réception des auteurs classiques dans l'éspace cultural portugais: une questione ouvert", in C. Leonardi, B. Munk Olsen (eds.), The Classical Tradition in the Middle Ages and Renaissance, Spoleto, 47-56.

Nascimento, A. A. (1997), "Traduzir, verbo de fronteira nos contornos da Idade Média”, in C. Almeida Ribeiro, M. Madureira (eds.), O género do texto medieval, Lisboa, 113-138.

Nascimento, A. A. (1999), Cister. Os documentos primitivos. No 9.० Centenário da fundação de Cister (1999). Introdução, tradução e notas de Aires A. Nascimento, Lisboa.

Navarro Caballero, M. (2003), "Mujer de notable: representación y poder en las ciudades de la España imperial”, in S. Armani, B. Martineau-Hurlet, A. U. Stylow, (eds.), Acta antiqua Complutensia IV. Epigrafía y sociedad en Hispania durante el Alto Imperio: estructuras sociales, Alcalá de Henares, 119-127.

Nemeti, S. (1998), "Cultul lui Sucellus-Dis Pater şi al Nantosueltei-Proserpina în Dacia romană”, EphemNapoc 8: 95-121.

Neumann, G., Untermann, J. (eds.) (1980), Die Sprachen im Römischen Reich der Kaiserzeit. Beihefte der Bonner Jabrbücher 40, Bonn.

Nicosia, F. (ed.) (1990), Un decennio di ricerche a Roselle. Statue e ritratti, Firenze.

Nunes, E., Albuquerque, M. (1968), "Parecer do doutor 'Valasco di Portogallo' sobre o beneplácito régio (Florença, 1954)”, in V. Rau (ed.), Do tempo e da bistoria, Lisboa, t. 2, 97-139.

Ober, J. (1989), Mass and Elite in Democratic Athens. Rhetoric, Ideology, and the Power of the People, Princeton.

Odiot, T. (2004), "Le site du Molard à Donzère", in Brun, J.-P., Poux, M., Tchernia, A. (eds.), Le vin. Nectar des Dieux. Génies des Hommes, Gollion, 202-203. 
Oelmann, F. (1914), Die Keramik des Kastells Niederbieber, Frankfurt.

Ohly, D. (1976), Die Aegineten: die Marmorskulpturen des Tempels der Aphaia auf Aegina. (a) I. Die Ostgiebelgruppe. München. (b) II. Die Westgiebelgruppe. III. Altarplatzgrupen, Akrotere, etc, München.

Olteanu, T. (2008), "El culto a Victoria y la interpretatio indígena en el Occidente de Hispania, Gallia y el norte de Britania", BVallad 74: 197-224.

Ors, A. de (1953), Epigrafia juridica de la España romana, Madrid.

Pacaut, M. (1993), Les moines blancs. Histoire de l'Ordre de Cîteaux, Paris.

Pallottino, M. (1952), "El problema de las relaciones entre Cerdeña e Iberia en la antigüedad prerromana", Ampurias 14: 137-155.

Panciera, S. (2003), "Umano, sovraumano o divino? Le divinità augustee e l'imperatore a Roma", in L. de Blois, P. Erdkamp, O. Hekster, G. De Kleijn, S. Mols, (eds.), The Representation and Perception of Roman Imperial Power. Proceedings of the Third Workshop of the International Network Impact of Empire (Roman Empire c. 200 B.C. - A.D. 476), Amsterdam, 219-239.

Paparelli, G. (1973), Feritas, humanitas, diuinitas. L'essenza umanistica del Rinascimento, Napoli.

Parker, V. (1988), "Túpavvoc. The semantics of a political concept from Archilochus to Aristotle", Hermes 126. 2: 145-172.

Patillon, M. (ed.) (2002), Pseudo-Aelius Aristide, Arts rhétoriques, Paris.

Pekary, T. (1968), Untersuchungen zu den römischen Reichsstraßen, Bona.

Pellegrini, D. P. M. (2003), Le Grandi Storie dell'Auto, vol. 2, Alfa Romeo, 35-35.

Pelling, Ch. (2002), "Speech and action: Herodotus' Debate on the Constitutions", PCPhS 48: 123-158.

Peña Cervantes, Y. (2010), Torcularia. La producción de vino y aceite en Hispania. Catálogo de yacimientos analizados en cedé (Sèrie documenta 149), Tarragona.

Pensa, M. (1979), "Genesi e svilupo dell'arco onorario nella documentazione numismática”, Studi sull'Arco Onorario Romano, Roma, 19-27.

Peres, D. (1952), História de Portugal, II, Porto.

Pérez Martin, A. (1979), Proles Aegidiana. I. Introducción. Los Colegiales desde 1368 a 1500 , Bolonia.

Pérez Martin, A. (1999), Españoles en el Alma Mater Studiorum. Profesores hispanos en Bolonia (de fines del siglo XII a 1799), Murcia.

Pérez Ruiz, F. (1984), "El justo es feliz y el injusto desgraciado, justicia y felicidad en la República de Platon", Pensamiento 40, 159: 257-295.

Petrarca, F. (1581), Francisci Petrarchae Florentini Opera. Basileae, per Sebastianum Henricpetri. 
Petrarca, F. (1942), Epistolae familiares, in V. Rossi (ed.), Le Familiari, Firenze.

Petri, Ch. (1989), 'La politique de Constance II: un premier 'césaropapisme' ou l'imitatio Constantini?", in A. Dihle (coord.), L'église et l'empire au IV siècle, Genève, 113-178.

Pfeiffer, R. (1949-1951), Callimachus, 2 vols., Oxford.

Pflaum, H.G. (1976), Inscriptions latines de l'Algérie, t. II, vol. II, Inscriptions de la Confédération cirtéenne, de Cuicul et de la tribu des Suburbures, Alger.

Pflug, H. (1941), As auto-estradas do Reich, Berlim.

Pharr, C. et alii (2008), The Theodosian Code and Novels and the Sirmondian Constitution. Translation, commentary and bibliography, Union (NJ).

Piana, C. (1976), Nuovi documenti sull'Universitá di Bologna e sul Collegio di Spagna,I-II, Bolonia, Zaragoza.

Pick, B. (1898), Die antiken Münzen Nordgriechenlands I, 2. Die antiken Münzen von Dacien und Moesien, Berlin.

Piganiol, A. (1972, 2a ed.), L'empire chrétien, Paris.

Pina, R. de (1977), Chronica do Senhor Rey D. Affonso V, cap. CXXV "Das feiçoões custumes e virtudes do Yfante Don Pedro”, in M. L. de Almeida (Intro. e Revisão), Crónicas de Rui de Pina, Porto.

Pinheiro Futre, M. P. (2006), "Do Mito à Utopia: viagem ao mundo do imaginário grego" in Actas do V Congresso da APEC-Antiguidade Clássica e nós: Herança e Identidade Cultural, Braga, 569-581.

Pinho, S. T. (1999), "Os Príncipes de Avis e o Pré- Humanismo Português", in Raizes Greco-Latinas da Cultura Portuguesa. Actas do I Congresso da APEC, Coimbra, 99-133.

Pinto, Frei H. (1952), "Diálogo da justiça”, in Imagem da vida cristã, I, Lisboa.

Pippidi, D. M. (1971), I Greci nel Basso Danubio dall'età arcaica alla conquista romana, Mailand.

Pirling, R. (1993), "Ein Trierer Spruchbecher mit ungewöhnlicher Inschrift aus Krefeld-Gellep", Germania 71: 387-404.

Podlecki, A. J. (1976), “Athens and Aegina”, Historia 25.4: 396-413.

Poenaru Bordea, G. (1979), "Les statères ouest-pontiques de type Alexandre le Grand et Lysimaque”, RBNS 125: 37-51.

Prag, J. R. W. (2002), "Epigraphy by numbers: Latin and the epigraphic culture in Sicily", in A. E. Cooley (ed.), Becoming Roman, Writing Latin? Literacy and Epigraphy in the Roman West. JRA Suppl. Ser. 48: 15-31.

Preda, C., Popescu, E., Diaconu, P. (1962), "Săpăturile arheologice de la Mangalia (Callatis)", Materiale 8: 439-455.

Pressouyre, L. (1990), Le rêve cistercien, Paris. 
Price, S. R. F. (1984), Rituals and Power. The Roman Imperial Cult in Asia Minor, Cambridge.

Privitera, G. A. (1988), "Pindaro, Nem. III 1-5 e l'acqua di Egina”, QUCC 58: 63-70.

Puerta Torres, C. (1995), Los miliarios de la Vía de la Plata, 1-2, Madrid.

Quadrino, D. (2007), Una nuova iscrizione onoraria di Adriano e il Sebasteion di Kestros in Cilicia Tracheia, Tivoli.

Radnoti Alföldi, M., Rasbach, G. (1999), "Zur Frage der interpretatio Romana“, in Festschrift für Günter Smolla, Wiesbaden, 597-605.

Raepsaet-Charlier, M. Th. (1975), "La datation des inscriptions latines dans les provinces occidentales de l'Empire Romain d'après les formules " In $\mathrm{H}$ (onorem) D(omus) D(ivinae) » et «Deo, Deae »", in ANRW II 3: 232-282.

Raepsaet-Charlier, M. Th. (2005), "Les sacerdoces des femmes sénatoriales sous le Haut-Empire", in M.-F. Baslez, F. Prévot (eds.), Prosopographie et histoire religieuse. Actes du colloque tenu en l'Université Paris XII-Val de Marne le 27 E 28 octobre 2000, Paris, 283-304.

Ramalho, A. C. (1985), Latim Renascentista em Portugal (Antologia), Coimbra.

Rapp, Cl. (2005), Holy Bishops in Late Antiquity, The nature of Christian Leadership in an age of transition, Berkeley.

Rau, V. (1969), "Italianismo na cultura jurídica portuguesa do século XV", Revista Portuguesa de História 12.1: 185-206.

Rau, V. (1973), "Studenti ed eruditi portoghesi in Italia nel secolo XV", Estudos Italianos em Portugal 36: 7-73.

Rawlinson, H. G. (1916), Intercourse between India and the Western World from the Earliest Times to the Fall of Rome, Cambridge.

Rebelo, D. L. (1951), Do governo da republica pelo rei (de republica gubernanda per regem), reprodução fac-similada da edição de 1496, Introdução e notas de A. M. de Sá, Lisboa.

Rebelo, L. de S. (1983), A concep̧̣ão do poder em Fernão Lopes, Lisboa.

Rebuffat, R. (2007), "Pour un corpus des bilingues punico-libyques et latinolibyques", in M. H. Fantar (ed.), Osmose etnho-culturelle en Méditerranée, Tunis, 183-242.

Regra do Patriarca S. Bento (1992), Edições “Ora \& Labora”, Singeverga.

Rhodes, P. J. (1993), A Commentary on the Aristotelian ATHENAION POLITEIA, Oxford.

Rhodes, P. J. (2006), A History of the Classical Greek World 478-323 BC, Molden. RIB = Collingwood, R. G. (1965), The Roman inscriptions of Britain. I. Inscriptions on stone, Oxford. 
RIG = P.-M. Duval (ed.), Recueil des inscriptions gauloises, Paris 1985-. I: M. Lejeune, Textes gallo-grecs, 1985; II.1: M. Lejeune, Textes gallo-étrusques. Textes gallo-latins sur pierre, 1988; II.2: P.-Y. Lambert, Textes gallo-latins sur instrumentum, 2002; III: P.-M. Duval y G. Pinault, Les calendriers (Coligny, Villards d'Héria), 1988; IV: J.-B. Colbert de Beaulieu y B. Fischer, Les légendes monétaires, 1998.

Ripollés, P. P. (2004), "Coinage and identity in the Roman provinces: Spain", in Ch. Howgego, V. Heuchert, A. Burnett (eds.), Coinage and identity in the Roman provinces, Oxford, 79-93.

Ripollés, P. P., Velaza, J. (2002), "Saguntum, colonia latina”, ZPE 141: 285-294.

Rodgers, B. (1989), “The Metamorphosis of Constantine”, CQ 39.1: 233-246.

Rodrigues, M. A. (1993), "O infante D. Pedro e a Universidade”, Biblos. Revista de Faculdade de Letras (Coimbra). Actas do Congreso Comemorativo do $6^{\circ}$ Centenario do Infante D. Pedro (25 a 7 de Novembro de 1992) 69: 345362.

Rodrigues, N. S. (2007), "Entre Europa e Io: elementos orientais na arte grega arcaica e clássica", in J. A. Ramos, L. M. Araújo, A. Ramos dos Santos (eds.), Arte Pré-Clássica. Colóquio Comemorativo dos Vinte Anos do Instituto Oriental da Faculdade de Letras da Universidade de Lisboa, Lisboa, 323346.

Rodríguez, P., Díez de Pinos, E. (2014), "Nueva inscripción celtibérica en piedra de E1 Pueyo de Belchite (Zaragoza)", Palaeohispanica 14: 245-262.

Rodríguez Colmenero, A., Ferrer Sierra, S., Álvarez Asorey, R. (2004), Miliários e outras inscricións viarias romanas do noroeste hispánico. Santiago de Compostela.

Rocha Pereira, M. H. (1981), "O mais antigo texto europeu de teoria política", Nova Renascença 1: 364-370.

Rocha Pereira, M. H. (1990), “O 'Diálogo dos Persas’ em Heródoto”, Estudos Portugueses. Homenagem a António José Saraiva, Lisboa, 351-362.

Rocha Pereira, M. H. (2003), Hélade. Antologia da Cultura Grega, Asa, Porto.

Rocha Pereira, M. H. (2008, 8a ed.), Sófocles: Antígona, Coimbra.

Roha Pereira, M. H. (2009, 10ª ed.), Hélade, Lisboa, Guimarães.

Rocha Pereira, M. H. (2012), Estudos de História da Cultura Clássica, vol.1 Cultura Grega, Lisboa.

Roldán Hervás, J. (1975), Itineraria Hispana. Fuentes antiguas para el estudio de las vías romanas en la Peninsula Ibérica, Madrid.

Röllig, W. (1980), “Das Punische im Römischen Reich”, in G. Neumann, J. Untermann (eds.), Die Sprachen im Römischen Reich der Kaiserzeit. (Bonner Jabrbücher des Rheinischen Landesmuseums in Bonn im Landschaftsverband 
Bibliografia

Rheinland und des Vereins von Altertumsfreunden im Rheinlande 40), Köln, 285-299.

Romano, E. (2006-2009), "Le tombe "a cupa" in Italia e nel Mediterraneo. Tipologia architettonica, committenza e rituale”, StClOr 52: 149-219.

Romilly, J. de (1959), "Le classement des constitutions d'Hérodote à Aristote", REG 72: 81-99.

Rose, C. B. (1997), Dynastic Commemoration and Imperial Portraiture in the Julio-Claudian Period, Cambridge.

Rosenthal, F. (1936), Die Sprache der palmyrenischen Inschriften und ibre Stellung innerhalb des Aramäischen, Leipzig.

Rosivach, V. J. (1977), "Earthborns and Olympians: the parodos of the Ion", CQ 27. 2: 284-294.

Rosivach, V. J. (1988), "The Tyrant in Athenian Democracy", QUCC 59: 43-57.

Rossillon, Ph. (ed.) (1995), Atlas de la langue française, Paris.

Rossiter, J. J. (1978), Roman Farm Buildings in Italy (BAR int. Ser. 52), Oxford.

Rössler, O. (1980), "Libyen von der Cyrenaica bis zur Mauretania Tingitana", in G. Neumann, J. Untermann (eds.), Die Sprachen im Römischen Reich der Kaiserzeit. (Bonner Jabrbücher des Rheinischen Landesmuseums in Bonn im Landschaftsverband Rheinland und des Vereins von Altertumsfreunden im Rheinlande 40). Köln, 267-284.

Rubenstein, L. (2004), "Ionia", in M. H Hansen, T. H. Nielsen (eds.), An Inventory of Archaic and Classical poleis, Oxford, 1053-1107.

Rucquoi, A. (2003), "Rois et princes portugais chez les auteurs castillans du $\mathrm{XV}^{\mathrm{e} m e}$ siécle», Península. Revista de Estudos Ibéricos. Entre Portugal e Espanha. Relaçôes Culturais (sécolos XV-XVIII). In Honorem Jose Adriano de Freitas Carvalho, 0: 39-51.

Ruggini, L. C. (1989), "Felix Temporum Reparatio", in A. Dihle (coord.), Realtà socio-economiche in movimento durante un ventennio di regno (Costanzo II Augusto, 337-361 d.C.), L'église et l'empire au IV siècle, Genève, 179-243.

Rüpke, J. (2005), Fasti sacerdotum. Die Mitglieder der Priesterchaften und das sakrale Funktionspersonal römischer, griechischer, orientalischer und jüdischchristlicher Kulte in der Stadt Rom von 300 v. Chr. bis 499 n. Chr., Wiesbaden.

Rusjaeva, A., Vinogradov, Ju. G., (2000), "Apollon Ietros. Herrscher von Istros”, in A. Avram, M. Babeş (eds.), Olbia, Civilisation grecque et cultures antiques périphériques. Hommages à P. Alexandrescu à son $70^{\circ}$ anniversaire, Bucarest, 229-234.

Rutishauer, B. (2012), Athens and the Cyclades. Economic Strategies 540-314 BC, Oxford. Sabbadini, R. (1905), Le scoperte dei codici latini e greci ne' secoli XIV e XV , Florencia. 
Sabbadini, R. (1914), Le scoperte dei codici latini e greci ne' secoli XIV e XV, Florencia.

Saddington, D.B. (1999), "Roman soldiers, local gods and interpretatio Romana in Roman Germany", ActaCl 42:155-169.

Salazar, A. M. (1976), "El impacto humanístico de las misiones diplomáticas de Alonso de Cartagena en la Corte de Portugal entre medievo y renacimiento (1421-31)", in A. D. Deyermond (ed.), Medieval Hispanic Studies presented to Rita Hamilton, Londres, 215-226.

Salinas, M. (1995), "Los inicios de la epigrafía en Lusitania oriental", in F. Beltrán (ed.), Roma y el naámiento de la cultura epigráfica en Occidente, Zaragoça, 281-291.

Salway, B. (2001), "Travel, Itineraria and Tabellaria", in C. Adams and R. Laurence (eds.), Travel and Geography in the Roman Empire, Londres, Nova Iorque, 22-66.

Santo Agostinho (2009 12a ed. ), A cidade de Deus, trad. de Oscar Paes Leme, 2 v., Vozes, Petrópolis, São Paulo.

Santos, M. J. A. (1998), Vida e morte de um mosteiro cisterciense. S. Paulo de Almaziva - Séculos XIII-XV, Lisboa.

Saumagne, C. (1928), "Iter populo debetur", Révue d'Histoire, de Littérature et d'Histoire Anciennes 54: 320-353.

Scheer, T. S. (2003), "The Past in na Hellenistic Present: Myth and Local Tradition", in A. Erskine (ed.), A Companion to the Hellenistic World, Oxford, 216-231.

Scheid, J. (2015), "Les Augustea et le culte des empereurs. Réflexions sur les rites célébrés dans ces lieux de culte", in P. Gros, E. Marin, M. Zink (eds.), Auguste, son époque et l 'Augusteum de Narona. Actes du colloque organisé à l'Académie des Inscriptions et Belles-Letres et l'Université Catholique de Croatie (Zagreb) 12 décembre 2014, 17-30, Paris.

Schilardi, G. (ed.) (1997), Filostrato. Immagini, Lecce.

Schmidt, R. (1980), "Die Ostgrenze von Armenien über Mesopotamien, Syrien bis Arabien”, in G. Neumann, J. Untermann (eds.), Die Sprachen im Römischen Reich der Kaiserzeit. (Bonner Jahrbücher des Rheinischen Landesmuseums in Bonn im Landschaftsverband Rheinland und des Vereins von Altertumsfreunden im Rheinlande 40). Köln, 187-214.

Schmidt, Th., Fleury, P. (2011), Perceptions of the Second Sophistic and its Times. Regards sur la seconde sophistique et son époque, Toronto, Buffalo, London.

Schwartz, J. (1960), Pseudo-Hesiodeia: recherches sur la composition, la diffusion et la disparition ancienne d'oeuvres attribuées à Hésiode, Leiden.

Scott, K. (1936), The Imperial Cult under the Flavians, Stuttgart.

Sealey, R. (1976), A bistory of Greek city-states 700 -338 B. C. Berkeley. 
Seignobos, Ch. (1969), Histoire sincère de la nation française, Paris.

Semerari, L. (2000), Aula Magna Università degli Studi di Bari, Bari.

Sergent, B. (2006), "Sucellus et le tonneau", in Anthropology of the Indo-European World and Material Culture. Proceedings of the 5th International Colloquium of Anthropology of the Indo-European World and Comparative Mythology, Budapest, 61-80.

Serra, J. C. da (1972), Academia Real das Sciencias de Lisboa, II, cap. VII, Lisboa. Sforza, W. C. (1951), “Osservazioni sul 'De nobilitate legum' di Coluccio Salutati”, in E. Castelli (ed.), Umanesimo e Scienza politica (Atti del congresso Internazionale di Studi Umanistici, Roma-Firenze, 1949), Milano.

Shapiro, H.A. (1993), Personification in Greek art: the representation of abstract concepts 600-400 b.C., Zürich.

Shaw, M. H. (1982), “The $\tilde{\eta} \theta$ os of Theseus in 'The Suppliant Women”, Hermes 110. 1: 3-19.

Shorrock, R. (2011), The Myth of Paganism: Nonnus, Dionysus and the World of Late Antiquity, Bristol.

Sigeia, L. (1970), Dialogue de deux jeunes filles sur la vie de retraite (1552), Présenté, traduit et annoté par O. Sauvage (ed.), Paris.

Sillières, P. (1990), Les voies de communication de l'Hispanie méridionale, Paris.

Silva, N. J. E. G. (1964), Humanismo e Direito em Portugal no século XVI, Lisboa.

Simón, I. (2013), Los soportes de la epigrafía paleohispánica. Inscripciones sobre piedra, bronce y cerámica, Zaragoza, Sevilla.

Siniscalco, P. (2004, 5a ed.), Il cammino di Cristo nell'Impero romano, Roma, Bari.

Slavazzi, F. (2006), "Il ciclo di relievi della Kaisersaal del ginnasio di Vedio a Efeso", in Iconografía 2005. Immagini e immaginari dell'antichità classica al mondo moderno, Roma, 235-243

Smyth, A. C. (2011), Polis and Personification in Classical Athenian Art, Leiden.

Snodgrass, A. M. (1977), Archaeology and the rise of the Greek state, Cambridge.

Snodgrass, A. M. (1980), Archaic Greece. The age of experiment, Londres.

Soares, C. (2008), Platão. O Político. Tradução do grego, introdução e notas, Lisboa.

Soares, C. (2014), “Theoria e práxis política em Heródoto”, Cuadernos de Filología Clássica: Estudios griegos e indoeuropeus 24: 57-79.

Soares, N. C. (1994), O príncipe ideal no século XVI e a obra de D. Jerónimo Osório, Coimbra.

Soares, N. C. (2002), "O infante D. Pedro e a cultura portuguesa", Biblos. Revista da Faculdade de Letras 78:107-128. 
Sodano, A. R. (1970), Porphyrii Quaestionum Homericarum Liber I, Napoli.

Solas, J. G. (2008), “Escrito sobre la ciudad”, Pensar la publicidad, II, n. 2: 37-62.

Sordi, M. (1965), Il cristianesino e Roma, Bologna.

Sordi, M. (1984), I cristiani e l'impero romano, Milano.

Soria, A. (1956), Los humanistas de la Corte de Alfonso el Magnánimo (según los epistolarios), Granada.

Sousa, D. A. C. de (1946-1954), Memória dos livros do uso del Rey D. Duarte, in Provas da história genealógica da casa real portuguesa, tomo I, liv. III, Coimbra.

Sousa, R., Fialho, M. C., Haggag, M., Rodrigues, N. S. (2013), Alexandrea ad Aegyptum: The Legacy of Multiculturalism in Antiquity, Lisboa.

Spickermann, W. (1997), "Aspekte einer neuen regionalen Religion und der Prozess der "interpretatio" im römischen Germanien, Rätien und Noricum", in Römische Reichsreligion und Provinzialreligion, Tübingen, 145-167.

Spyridakis, S. (1968), “Zeus is Dead: Euhemerus and Crete”, CJ 63: 337-340.

Stafford, E., Herrin, J. (eds.) (2005), Personification in the Greek World from Antiquity to Byzantium, Burlington.

Statuta capitulorum generalium ordinis Cisterciensis ab anno 1116 ad annum 1786 edidit Josephus M. ${ }^{\text {ia } C a n i v e z ~(1933-1941), ~} 8$ vols., Louvain.

Stefan, A. (2005), "Le titre de filius Augustorum de Maximin et Constantin et la théologie de la tétrarchie", in M.-F. Baslez, F. Prévot (eds.), Prosopographie et histoire religieuse. Actes du colloque tenu en l'Université Paris XII-Val de Marne le 27 Eं 28 octobre 2000, Paris, 329-349

Stefani, G. (1986), "I cippi a botte della provincia Sardinia”, Nuovo bullettino Archeologico Sardo 3: 115-160.

Stefani, G. (1988), "Cippi a botte nella basilica di S. Saturnino a Cagliari”, Quaderni della Soprintendenza archeologica per le province di Cagliari e Oristano 5: 167-175.

Stegmann, A. (1977), "La place de la praxis dans la notion de 'raison d'État' ", in Théorie et pratique politiques à la Renaissance, Paris.

Steinbrecher, M. (1985), Der Delisch-Attischen Seebund und die AthenischSpartanischen Beziehungen in der Kimonischen Ära (478/77-462/1), Berlin.

Stemmer, K (ed.) (1995), Standorte - Kontext und Funktion antiker Skulptur, Berlin.

Sterckx, C. (2008), "Sucellos et le casque d'Hadès", in Philomythia. Mélanges offerts à Alain Moreau, Monts, 223-229.

Stern, J. (1996), Palaephatus. Peri Apiston: On Unbelievable Tales, Wauconda. 
Stern, J. (1999), "Rationalizing Myth: Methods and Motives in Palaephatus" in R. Buxton, R. (ed.), From Myth to Reason? Studies in the Development of Greek Thought, Oxford, 215-222.

Stewart, A. (1990), Greek Sculpture: an exploration, New Haven, Yale.

Storey, I. C. (2003), Eupolis poet of old comedy, Oxford.

Stowe Mead, G. R. (1901), Apollonius of Tyana, the Philosopher-Reformer of the First Century A.D., London.

Strassler, R. B. (ed.) (2007), Landmark Herodotus: The Histories, New York.

Strassler, R.B. (ed.) (2009), Landmark Herodotus: The Histories, New York.

Strootman, R. (2010), "Literature and the Kings", in Clauss, J., Cuypers, M. (eds.), A Companion to Hellenistic Literature, Malden, Oxford, 30-45.

Suberbiola Martínez, J. (1987), Nuevos concilios hispano-romanos de los siglos III y IV. La colección de Elvira, Málaga.

Szabó, Á. (2007), Daciai papság, Budapest.

Szabó, Á. (2008), "Sulla questione dello statuto giuridico dei sacerdoti provinciali durante il principato. Studio preliminare”, Iustum Aequum Salutare 4: 71-81.

Tamerl, I. (2008), Das Holzfass in der römischen Antike mit einer Studie zu Fassfunden in Raetien, Diplomarbeit presso l'Università di Innsbruck, consultabile presso la Universitäts- und Landesbibliothek Innsbruck DG43696.

Tate, J. (1927), “The Beginnings of Greek Allegory”, CR 41.6: 214-215.

Tchernia, A. (1986), Le vin de l'Italie romaine. Essai d'bistoire économique d'après les amphores (BEFAR 261), Rome.

Teive, D. de (1786), Epodos Que Cont'em Sentenças Uteis A todos os Homens, A's quaes se acrescentão Regras para a boa educação de hum principe. Trad. no vulgar em verso solto por Francisco de Andrade (conforme à ed. de Lisboa, 1565), Lisboa, Na Of. Patr. de Francisco Luiz Ameno.

Temporini, H. (1978), Die Frauen am Hofe Trajans. Ein Beitrag zur Stellung der Augustae im Principat, Berlin, New York.

Thomson de Grummond, N. (2006), Etruscan Myth. Sacred History, and Legend, Philadelphia.

Tomlin, R. S. O. (1987), "Was ancient British Celtic ever a written language? Two texts from Roman Bath", Bulletin of the Board of Celtic Studies 34: 18-25.

Topál,J. (1990), “Der Import der sogenannten Moselweinkeramik in Pannonien”, ReiCretActa 27-28: 177-184.

Tortorici, E. (1975), Castra Albana. Forma Italia, Regio I, Roma.

Touchard, J. (1959), Histoire des idées politiques, I. Paris [trad. port. Lisboa, 1970]. 
Tranoy, A. (1981), La Galice romaine, Paris.

Tuchelt, K. (1981), "Zum Problem Kaisareion-Sebasteion. Eine Frage zu den Anfängen des römischen Kaiserkultes”, MDAI, 31 : 167-186.

Ulbert, G. (1959), "Römische Holzfässer aus Regensburg”, Bayerische Vorgeschichtsblätter 24: 6-29.

Ullman, B. L. (1963), The humanism of Coluccio Salutati, Padova.

Ullmann, W. (1980), Radici del Rinascimento (tr. ital.), Roma, Bari.

Unz, R.K. (1985), "The Surplus of the Athenian phoros", GRBS 26: 21-42.

Ureña Prieto, M. H. (2001), Dicionário de Literatura Grega, Lisboa.

Valiño, A. (1999), "La cerveza en las fuentes romanas. Base textual y fijación de su importancia”, AncHistB 13: 60-71.

Van Haeperen, F. (2002), "Le collège pontifical (3ème s. a.C.-4ème s. p.C.)", Études de Philologie, d'Archéologie et d'Histoire Anciennes 39: 11-42.

Varner, E.R. (2004), Mutilation and transformation. Damnatio memoriae and Roman Imperial Portraiture, Leiden, Boston.

Várzeas, M. I. O. (2013), "Callimachus and the New Paths of Myth”, in R. Sousa et alii (coord.) Alexandrea ad Aegyptom: the legacy of multiculturalismo in antiquity. Lisboa.

Velaza, J. (2003), "Epigrafía ibérica emporitana: bases para una reconsideración”, Palaeohispanica 3: 179-192.

Velaza, J. (2003a), "Las inscripciones monetales”, in P. P. Ripollés, M. del M. Llorens, Arse-Saguntum. Historia monetaria de la ciudad y su territorio, Sagunto, 121-148.

Velaza, J. (2009), “Epigrafía y literacy paleohispánica en territorio vascón”, Palaeohispanica 9: 611-622.

Vergerio, P. P. (1934), “Epistolario di Pier Paolo Vergerio”, in L. Smith (ed.), Fonti per la storia d'Italia, vol. 74, Roma, 436-445.

Vierneisel, K., Zanker, P. (1979), Die Bildnisse des Augustus: Herrscherbild und Politik in kaiserlichen Rom, München.

Villar, F., Pedrero, R. (2001), “Arroyo de la Luz III”, Palaeohispanica 1: 235274.

Vinogradov, J. G. (2000), "Heilkundige Eleaten in den Schwarzmeergründungen”, in M. Dreher (ed.), Bürgersinn und staatliche Macht. Festschrift für Wolfgang Schuller zum 65. Geburtstag, Konstanz, 133-149.

Vittinghoff, F. (1951), Römische Kolonisation und Bürgerrechtspolitik unter Caesar und Augustus, Wiesbaden.

Vives, J., Marín, T., Martínez, G. (1963), Concilios visigóticos e hispano-romanos, Madrid, Barcelona. 
Voragine, T. (2004), Legenda Aurea. Apresentação do Cardeal Dom José Saraiva Martins e introdução do Doutor Aníbal Pinto de Castro. Tomo Segundo, Porto.

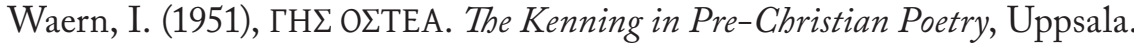

Wallace, M. B., Figueira, T. J. (2010), "Notes on the Island Phoros", ZPE 172: 65-69.

Wallace-Hadrill, A. (2005), "Mutatas formas: The Augustan Transformation of Roman Knowledge", in K. Galinsky (ed.), The Cambridge Companion to the Age of Augustus, Cambridge, 55-84.

Wallinga, H. T. (2005), Xerxes' Greek Adventure. The Naval Perspective, Leiden.

Walter, H. (1993), Ägina: die archäologische Geschichte einer griechischen Insel, München.

Walters, K. R. (1981), "Four Hundred Athenian Ships at Salamis?”, RbM 124: 199-203.

Wankel, H. (1983), "Thukydides 1,74,1 und die Schiffszahlen von Salamis," ZPE 52: 63-66.

Wells, J. (1923), Studies in Herodotus, Oxford.

Wesseling, P. (ed.) (1735), “Itinerarium Antonini Augusti”, Vetera Romanorum Itineraria, Amesterdão.

West, M. L. (1985), The Hesiodic Catalogue of Women: Its Nature, Structure, and Origins, Oxford.

Westrem, S. D. (2001), The Hereford Map. A Transcription and Translation of the Legend with Commentary, Turnhout.

Williams, D. (1987), "Aegina, Aphaia-Tempel XI: the pottery from the second limestone temple and the later history of the sanctuary", $A A$ : 629-680.

Williamson, G. (2004), "Aspects of identity", in C. Howgego, V. Heuchert, A. Burnett (eds.), Coinage and Identity in the Roman Provinces, Oxford, 19-27.

Winiarczyk, M. (2013), The «Sacred History» of Eubemerus of Messene, Berlin.

Witschel, Chr. (1995a), "Römische Tempelkultbilder und Römische Kaiserstatuen als Tempelkultbilder", in K. Stemmer, (ed.), Standorte. Kontext und Funktion antiker Skulptur; Ausstellungskatalog Abgußsammlung, Berlin, 250-265.

Witschel, Chr. (1995b), "Statuen auf römischen Platzanlagen unter besonderer Berücksichtigung von Timgad (Algerien)", in K. Stemmer (ed.), Standorte. Kontext und Funktion antiker Skulptur; Ausstellungskatalog Abgußsammlung, Berlin, 332-358.

Witschel, Chr. (2002), "Zum Problem der Identifizierung von munizipalen Kaiserkultstätten”, Klio 84: 114-124. 
Wlosok, A. (ed.) (1978), Römischer Kaiserkult, Darmstadt.

Wojciechowski, P. (2002), "Il culto di Beleno ad Aquileia romana. Origini, interpretatio Romana e la cosiddetta rinascita celtica", in Gli echi della terra. Presenze celtiche in Friuli. Dati materiali e momenti dell' immaginario. Convegno di studi, Castello di Gorizia, 5 - 7 ottobre 2001, Pisa, 29-35.

Woodard, R. (ed.) (2007), The Cambridge Companion to Greek Mythology, Cambridge.

Woodhead, A. G. (1962), The Greeks in the West. London. (Trad. port., Os Gregos no Ocidente).

Woolf, G. (1996), "Monumental writing and the expansion of the Roman society in the Early Empire", JRS 86: 22-39.

Woolf, G. (2002), "Afterword. How the Latin West was won”, in A. Cookey (ed.), Becoming Roman, writing Latin? Literacy and Epigraphy in the Roman West, JRA Suppl. Ser. 48: 181-188.

Yatromanolakis, Y. (2005), "Poleos erastes. The Greek city as the beloved", in E. Stafford, J. Herrin (eds.), Personification in the Greek World: From Antiquity to Byzantium, London, 267-284.

Young, T. Cuyler (1980), “480/479 B.C. - A Persian Perspective”, Iranica Antiqua 15: 213-39.

Zamora, J. A. (2005), "La práctica de escribir entre los primeros fenicios peninsulares y la introducción de la escritura entre los pueblos paleohispánicos”, Palaeohispanica 5: 155-19.

Zanichelli, G. Z. (2005), "Il mito di Troia nell'immaginario medievale”, in G. Burzacchini (coord.), Troia tra realtà e leggenda, Parma.

Zanker, P. (1983), Provinzielle Kaiserporträts. Zur Rezeption der Selbstdarstellung der Princeps, München.

Zaoli, G. (1912), “Lo Studio bolognese e papa Martino V”, Studi e Memorie per la storia dell'Università di Bologna I - série v. III: 105-188.

Zecchini, G. (ed.) (2015), L'Augusteum di Narona. Atti della Giornata di Studi. Roma 31 maggio 2013, (Centro ricerche e documentazione sull'antichità clàssica, monografie, 37), Roma.

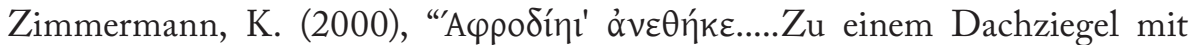
Votivinschrift", in A. Avram, M. Babeş (eds), Olbia, Civilisation grecque et cultures antiques périphériques. Hommages à $P$. Alexandrescu à son $70^{\circ}$ anniversaire, Bucarest, 239-251.

Zurara, G. E. de (1972), Chronica do Conde Dom Pedro de Meneses, II, Lisboa. 